\title{
BVOC-aerosol-climate interactions in the global aerosol-climate model ECHAM5.5-HAM2
}

\author{
R. Makkonen ${ }^{1,}$, A. Asmi ${ }^{1}$, V.-M. Kerminen ${ }^{1,2}$, M. Boy ${ }^{1}$, A. Arneth ${ }^{3,4}$, A. Guenther ${ }^{5}$, and M. Kulmala ${ }^{1}$ \\ ${ }^{1}$ Department of Physics, University of Helsinki, P.O. Box 64, 00014 University of Helsinki, Finland \\ ${ }^{2}$ Finnish Meteorological Institute, P.O. Box 503, 00101 Helsinki, Finland \\ ${ }^{3}$ Department of Physical Geography and Ecosystems Analysis, Lund University, 22362 Lund, Sweden \\ ${ }^{4}$ Institute of Meteorology and Climate Research, Karlsruhe Institute of Technology, Kreuzeckbahnstr. 19, \\ 82467 Garmisch-Partenkirchen, Germany \\ ${ }^{5}$ Atmospheric Chemistry Division, National Center for Atmospheric Research, Boulder, Colorado, 80301, USA \\ *now at: Department of Geosciences, University of Oslo, P.O. Box 1047, 0316 Oslo, Norway
}

Correspondence to: R. Makkonen (risto.makkonen@helsinki.fi)

Received: 22 March 2012 - Published in Atmos. Chem. Phys. Discuss.: 10 April 2012

Revised: 17 September 2012 - Accepted: 9 October 2012 - Published: 2 November 2012

\begin{abstract}
The biosphere emits volatile organic compounds (BVOCs) which, after oxidation in the atmosphere, can partition on the existing aerosol population or even form new particles. The large quantities emitted provide means for a large potential impact on both aerosol direct and indirect effects. Biogenic responses to atmospheric temperature change can establish feedbacks even in rather short timescales. However, due to the complexity of organic aerosol partitioning, even the sign of these feedbacks is of large uncertainty. We use the global aerosol-climate model ECHAM5.5-HAM2 to explore the effect of BVOC emissions on new particle formation, clouds and climate. Two BVOC emission models, MEGAN2 and LPJ-GUESS, are used. MEGAN2 shows a $25 \%$ increase while LPJ-GUESS shows a slight decrease in global BVOC emission between years 2000 and 2100 . The change of shortwave cloud forcing from year 1750 to 2000 ranges from -1.4 to $-1.8 \mathrm{~W} \mathrm{~m}^{-2}$ with 5 different nucleation mechanisms. We show that the change in shortwave cloud forcing from the year 2000 to 2100 ranges from 1.0 to $1.5 \mathrm{~W} \mathrm{~m}^{-2}$. Although increasing future BVOC emissions provide $3-5 \%$ additional $\mathrm{CCN}$, the effect on the cloud albedo change is modest. Due to simulated decreases in future cloud cover, the increased CCN concentrations from BVOCs can not provide significant additional cooling in the future.
\end{abstract}

\section{Introduction}

Anthropogenic aerosols alter the radiative fluxes directly by scattering and absorbing radiation, and indirectly by altering cloud albedo (Twomey, 1974), lifetime (Albrecht, 1989) and other properties (Pincus and Baker, 1994; Brenguier et al., 2000; Devasthale et al., 2005; Koren et al., 2005). The indirect radiative perturbation of anthropogenic aerosol (aerosol indirect forcing) exceeds the magnitude of the direct effect (Quaas et al., 2009), and the combined total aerosol forcing can be similar in magnitude (but opposite in direction) to the forcing of $\mathrm{CO}_{2}:-1.2 \pm 0.4 \mathrm{~W} \mathrm{~m}^{-2}$ (Quaas et al., 2009), $-1.3 \mathrm{~W} \mathrm{~m}^{-2}$ (Forster et al., 2007), $-1.6 \mathrm{~W} \mathrm{~m}^{-2}$ (Hansen et al., 2011; Makkonen et al., 2012). The negative presentday radiative forcing of aerosols could be diminishing with emission reductions in primary aerosols and aerosol precursors (Andreae et al., 2005). Kloster et al. (2008) showed that the aerosol forcing could weaken by $1.13 \mathrm{~W} \mathrm{~m}^{-2}$ already by 2030 with maximum feasible reductions. Makkonen et al. (2012) showed that the total aerosol forcing reduction until the year 2100 could be as much as $1.4 \mathrm{~W} \mathrm{~m}^{-2}$.

There are several natural aerosol feedbacks that respond to the changing climate (Carslaw et al., 2010). These include the severity (Amiro et al., 2009) and occurence (Gillett et al., 2004; Westerling et al., 2006) of wildfires, changes in DMS fluxes (Charlson et al., 1987), changes in sea salt emission due to changes in wind speed (Korhonen et al., 2010), and 
changes in dust emissions (Tegen et al., 2004). One potentially important feedback is the link between climate and emissions of biogenic volatile organic compounds (BVOC) and the formation of secondary organic aerosol (SOA) (Kulmala et al., 2004; Carslaw et al., 2010). By acting as a negative feedback, an increase in the ambient temperature could increase BVOC emissions, which in turn could not only increase the SOA burden but also provide growth for small particles leading to increased cloud condensation nuclei (CCN) concentrations, and cooling the climate via aerosol indirect effects. However, it is possible that the future increase in $\mathrm{CO}_{2}$ concentrations would act to inhibit emissions of certain biogenic VOCs (Arneth et al., 2007; Heald et al., 2009; Carslaw et al., 2010), leading even to a decreased SOA concentration in the future. Also, Scots Pine trees might require an increase in both $\mathrm{CO}_{2}$ and temperature for a large increase in monoterpene emission (Räisänen et al., 2008).

The net effect of BVOC emissions on the radiation budget is highly uncertain. The increased aerosol mass from BVOCs enhances the scattering of shortwave radiation, leading to a negative present-day aerosol direct effect. O'Donnell et al. (2011) estimated a SOA direct effect of $-0.31 \mathrm{~W} \mathrm{~m}^{-2}$, which includes also the minor anthropogenic contribution. A review by Carslaw et al. (2010) summarized a 25 to $150 \%$ increase in aerosol burden due to SOA between present-day and year 2100 , leading to a global mean direct radiative perturbation of -0.04 to $-0.24 \mathrm{~W} \mathrm{~m}^{-2}$.

The effect of BVOCs on the aerosol indirect effect is sensitive to which aerosol size range the organics will condense onto, which is dependent on both the existing aerosol size distribution and the volatility distribution of the condensing species. In the case of a low condensation sink, low-volatility organics help the growth of newly-formed particles, increasing the number concentration of $\mathrm{CCN}$ and cloud droplets, leading to a stronger indirect effect. However, the condensation of organic vapours will also increase the condensation and coagulation sink, leading to decreased particle nucleation rates and enhanced losses of small particles, possibly decreasing the indirect effect. The effect of an increased sink was shown by O'Donnell et al. (2011): the indirect effect of present-day SOA was found to be $+0.23 \mathrm{~W} \mathrm{~m}^{-2}$, almost equal but opposite in sign to the direct radiative effect. However, O'Donnell et al. (2011) did not consider the growth of nucleated particles by VOCs. Makkonen et al. (2012) explored the effect of a potential increase in future BVOC emissions by a simple $+50 \%$ BVOC scenario. The resulting increased growth of sub-CCN particles lead to an increase in cloud droplet number concentration and an additional $-0.4 \mathrm{~W} \mathrm{~m}^{-2}$ total radiative forcing (direct + indirect effects).

While atmospheric organics are globally responsible for a large part of the aerosol growth, they can also participate in the aerosol formation process itself. Metzger et al. (2010) showed that atmospheric concentrations of sulphuric acid and organic vapours in a smog chamber lead to a particle formation rate proportional to the product of sulphuric acid and organic concentration, which would imply a critical cluster consisting of one molecule of each. Ortega et al. (2012) showed that the oxidation products of limonene, $\alpha$-pinene, and $\Delta^{3}$-carene can form new particles. In addition, quantum chemical calculations indicate that initial clusters containing limononic acid are as stable as pure sulphuric acid clusters, and that it is energetically more favourable to add organic acids than sulphuric acid to a cluster with one or few sulphuric acid molecules (Ortega et al., 2012). It is clear that organic molecules have an important role in the nucleation and growth of sub- $4 \mathrm{~nm}$ particles, but the contribution varies from one location to another (Paasonen et al., 2010).

In this study we focus on the role of BVOCs on new particle formation, aerosol growth, cloud properties and climate. We implement biogenic emissions from two mechanistically different vegetation models, which give BVOC emissions fields with significant spatial differences. Also, the response of the two models to changing climate and atmospheric composition is different: one model shows a future global increase of $+25 \%$ in global monoterpene emissions due to climate change, while the other one shows a slight decrease due to $\mathrm{CO}_{2}$ inhibition. We also explore the effect of several proposed boundary layer nucleation mechanisms.

\section{Methods}

\subsection{The ECHAM5.5-HAM2 model}

We use the global aerosol-climate model ECHAM5.5HAM2 (Zhang et al., 2012) coupled to cloud droplet activation model (Lohmann et al., 2007). The cloud droplet activation is parameterized according to Abdul-Razzak and Ghan (Abdul-Razzak and Ghan, 2000; Stier et al., 2012). The aerosol microphysics model inside ECHAM5.5-HAM2 is M7 (Vignati et al., 2004), which includes condensation, coagulation and nucleation, and describes the aerosol size distribution by seven log-normal modes. The modeled compounds are black carbon, organic carbon, sulfate, dust and sea salt. Nitrate aerosols are not considered.

All model simulations are performed with fixed seasurface temperatures and sea-ice distribution. While oneyear simulations would be enough for retrieving aerosol quantities, we integrate the model for five years to reduce model noise for cloud-related variables (CDNC, cloud forcing). In our analysis, we focus on concentrations of condensation nuclei $\left(\mathrm{CN}, d_{\mathrm{p}}>3 \mathrm{~nm}\right)$, cloud condensation nuclei at $0.2 \%$ supersaturation $(\mathrm{CCN}(0.2 \%))$ and cloud droplet number (CDNC). We further diagnose the change in cloud albedo, $\Delta \mathrm{Rc}$, as (Twomey, 1991)

$\Delta \mathrm{Rc}=\mathrm{Rc}(1-\mathrm{Rc}) / 3 \ln \left(\frac{\mathrm{CDNC}}{\mathrm{CDNC}_{\mathrm{REF}}}\right)$, 
where $\mathrm{Rc}$ is the initial cloud albedo (assumed 0.35), $\mathrm{CDNC}_{\mathrm{REF}}$ is the reference concentration and $\mathrm{CDNC}$ is the perturbed concentration. The CDNC used in Eq. (1) is sampled at the cloud top. The above equation is used to analyze changes since the pre-industrial period $\left(\Delta \mathrm{Rc}_{1750}, \mathrm{CDNC}_{\mathrm{REF}}=\mathrm{CDNC}_{1750}\right)$ and also changes in the cloud albedo between present-day and future $\left(\Delta \mathrm{Rc}_{2000}\right.$, $\left.\mathrm{CDNC}_{\mathrm{REF}}=\mathrm{CDNC}_{2000}\right)$. Change in the low-cloud fraction, $\triangle \mathrm{LCF}$, is used to diagnose indirect effects beyond the cloud albedo effect. The low-cloud fraction is analysed with standard ECHAM5 postprocessing from clouds with model level $1.0>\sigma>0.8$. Finally, changes in cloud forcing between simulations are analysed. Shortwave cloud forcing (SWCF) is calculated as the difference between all-sky and clear-sky top-of-atmosphere shortwave radiative fluxes.

\subsubsection{Aerosol nucleation}

The binary sulphuric acid-water nucleation (Vehkamäki et al., 2002) is included in all simulations. This formulation produces a band of particles in the upper troposphere-lower stratosphere (UTLS). It has been shown that binary sulphuric acid-water nucleation is not able to explain the observed number concentrations in lower atmosphere (Spracklen et al., 2006; Makkonen et al., 2009).

Several global models (Spracklen et al., 2006; Makkonen et al., 2009; Pierce and Adams, 2009; Wang and Penner, 2009) have implemented activation-type nucleation (Kulmala et al., 2006) to provide a source of new particles in the boundary layer. According to the theory, sulphuric acid activates sub-2 nanometer clusters resulting in nucleation rate linearly dependent of sulphuric acid concentration

$J_{2}=A_{\mathrm{SA} 1}\left[\mathrm{H}_{2} \mathrm{SO}_{4}\right]$

Spracklen et al. (2010) showed that activation-type nucleation can clearly improve modeled particle number concentrations and intra-annual variations compared to modifications to primary emission size distributions. Here, we implement activation-type nucleation with the activation coefficient of $A_{\mathrm{SA} 1}=1.7 \times 10^{-6} \mathrm{~s}^{-1}$ according to Paasonen et al. (2010). Activation-type nucleation by sulphuric acid Eq. (2) is referred to as SULACT.

To account for the effect of organics on the nucleation process, we apply two additional nucleation schemes. The first scheme assumes that both sulphuric acid and organics can activate a cluster:

$J_{2}=A_{\mathrm{SA} 2}\left[\mathrm{H}_{2} \mathrm{SO}_{4}\right]+A_{\mathrm{ORG}}[\mathrm{ORG}]$,

where [ORG] is the concentration of organic vapour participating nucleation, $A_{\mathrm{SA} 2}=6.1 \times 10^{-7} \mathrm{~s}^{-1}$ and $A_{\mathrm{ORG}}=$ $0.39 \times 10^{-7} \mathrm{~s}^{-1}$ (Paasonen et al., 2010). It should be noted that the activation coefficient for sulphuric acid is $64 \%$ lower than in Eq. (2), and that the activation coefficient for sulphuric acid $A_{\mathrm{SA} 2}$ is 16 times higher than the activation coefficient for organics $A_{\mathrm{ORG}}$. The Eq. (3) is referred to as
ORGSULACT in the paper. The second nucleation scheme to account for organics assumes kinetic heteromolecular nucleation of sulphuric acid and organics, or activation by other vapour of a cluster containing the other

$J_{2}=K_{\mathrm{HET}}\left[\mathrm{H}_{2} \mathrm{SO}_{4}\right][\mathrm{ORG}]$,

where $K_{\mathrm{HET}}=11 \times 10^{-14} \mathrm{~s}^{-1}$ (Paasonen et al., 2010). Eq. (4) is referred to as ORGSULHET in the paper. The parameterisations in Eqs. (3) and (4) are based on organic vapour concentration [ORG] analyzed from observed particle growth rates. Our model setup does not include marine sources of BVOC and gas phase organics are not transported, hence ORGSULHET does not produce nucleation in the marine boundary layer (MBL). To further address the uncertainties in MBL nucleation, we conduct simulations with activation-type nucleation (Eq. 2), but turn off nucleation in the MBL. This experiment is referred to as SULACT_TER.

Since nucleated particles are typically $1-2 \mathrm{~nm}$ in diameter, we apply the formulation by Kerminen and Kulmala (2002) to transfer the freshly formed particles to nucleation mode as $3 \mathrm{~nm}$ particles. The growth of sub- $3 \mathrm{~nm}$ particles is calculated from gas-phase sulphuric acid and organics.

\subsubsection{Gas-phase organics and SOA formation}

Due to the complexity of atmospheric organic chemistry, global models struggle to find a balance between computational efficiency and realistic description of SOA. Most simplistic approaches treat SOA from VOCs as a primary aerosol with constant size distribution (Stier et al., 2005). This approach can be improved by partitioning the SOA to the existing particle population according to the condensation sink (Makkonen et al., 2009). Further complexity can be added with two-product SOA formation models (O'Donnell et al., 2011; Yu, 2011) or volatility basis-set (VBS) approach (Donahue et al., 2011; Riipinen et al., 2011). Depending on the implementation, thermodynamic partitioning of SOA might only increase organic mass in sizes with organics available, not being able to explaing the growth of small particles (O'Donnell et al., 2011). The VBS approach contains several unknown parameters and does not necessarily improve the modeled SOA distribution.

In this paper we apply an approach similar to that in Makkonen et al. (2009). Monoterpenes from biogenic emissions are assumed to be evenly distributed to the boundary layer. We assume that the monoterpenes form SOA with a yield of $15 \%$. This organic mass is assumed to condense irreversibly to the aerosol phase during one timestep (20 min), and no organics are traced in the gas phase. We further assume that $50 \%$ of the organics cabable of forming SOA can contribute to the nucleation process ([ORG] in Eqs. 3 and 4). 


\subsection{Aerosol and precursor emissions}

\subsubsection{Anthropogenic emissions}

We consider the anthropogenic emissions of sulphur dioxide and primary $\mathrm{OC}$ and $\mathrm{BC}$ aerosols. The sulphur dioxide emissions are divided between high-elevation (industry, powerplant, shipping) and low-elevation (domestic, road, off-road) emissions. The applied emission inventories include only aerosol mass, which has to be converted to aerosol number concentrations. It is assumed that $2.5 \%$ of the emitted gaseous sulphur dioxide partitions to aerosol phase in subgrid-scale processes, and this sulfate is assumed to form Aitken, accumulation and coarse mode partices according to Stier et al. (2005). This approach for subgrid-scale sulfate conversion adds very little particle number into a grid box.

The primary aerosol emission size distribution assumed here is identical to Stier et al. (2005). The number mean radius of $\hat{r}=0.03 \mu \mathrm{m}$ a standard deviation of $\sigma=1.59$ is assumed for black carbon and organic carbon emissions from fossil-fuel and biofuel. Wildfires are assumed to emit larger carbonaceous particles of radius $\hat{r}=0.075 \mu \mathrm{m}(\sigma=1.59)$. The primary emissions sizes used by Stier et al. (2005) are larger than the AeroCom recommendations (Dentener et al., 2006), however the recommendations are constructed based on measurements of rather freshly-emitted particles and might not be suitable for global model grids of size $>200 \times 200 \mathrm{~km}$. The anthropogenic emissions do not include any intra-annual variation.

The anthropogenic emissions for the year 1750 are taken from the AeroCom dataset presented in Dentener et al. (2006). Although coal burning made a minor contribution already in the pre-industrial era, the emissions from fossil fuels are neglected in the dataset. Anthropogenic emissions of BC, $\mathrm{POM}$ and $\mathrm{SO}_{2}$ from biofuel are $0.39,1.56$ and $0.12 \mathrm{Tg} \mathrm{yr}^{-1}$, respectively.

The present-day emissions follow AeroCom recommendations (Dentener et al., 2006), applied according to Stier et al. (2005). The emissions of $\mathrm{BC}, \mathrm{POM}$ and $\mathrm{SO}_{2}$ from biofuels are 1.6, 9.1 and $9.6 \mathrm{Tg} \mathrm{yr}^{-1}$, respectively. Fossil fuels contribute by 3.0, 3.2 and $54 \mathrm{Tg} \mathrm{yr}^{-1}$ for $\mathrm{BC}, \mathrm{POM}$ and $\mathrm{SO}_{2}$, respectively.

For the future experiments, we apply the "Representative Concentration Pathways" (RCP), which are scenarios developed for IPCC AR5 (Moss et al., 2010; Lamarque et al., 2011). We use three of the four available scenarios: RCP2.6 (van Vuuren et al., 2007), RCP-4.5 (Clarke et al., 2007; Smith and Wigley, 2006; Wise et al., 2009) and RCP-8.5 (Riahi et al., 2007). The scenarios vary greatly in terms of the radiative forcing during the 21st century: in RCP-2.6 the radiative forcing peaks at $3.0 \mathrm{~W} \mathrm{~m}^{-2}$ before 2050 and declines to $2.6 \mathrm{~W} \mathrm{~m}^{-2}$ by 2100 , whereas in RCP- 8.5 it continues to increase rapidly until 2100 reaching a value $8.5 \mathrm{~W} \mathrm{~m}^{-2}$. In spite of the variability in the radiative forcing, many aerosol related emissions behave rather similarly between the path- ways. The $\mathrm{SO}_{2}$ emissions show a decrease by $77 \%, 79 \%$ and $88 \%$ until the year 2100 compared to the year 2000 in RCP8.5, RCP-4.5 and RCP-2.6, respectively. The reductions in black carbon and organic carbon are more subtle, ranging from $45 \%$ (RCP-8.5) to $57 \%$ (RCP-2.6) for BC and from $29 \%$ (RCP-2.6) to $46 \%$ (RCP-4.5) for OC.

The anthropogenic influence on wildfire emissions is taken into account. Wildfire emissions are modeled according to AeroCom for pre-industrial and present-day (Dentener et al., 2006), and according to each RCP pathway for the future.

\subsubsection{Biogenic VOC emissions}

We use two models for biogenic VOC emissions: MEGAN2 (Guenther et al., 2006) and LPJ-GUESS (Schurgers et al., 2009). Only monoterpene emissions are taken into account. The two models cover a wide range in terms of annual global monoterpene emissions for present-day, from $30 \mathrm{Tg}(\mathrm{C}) \mathrm{yr}^{-1}$ (LPJ-GUESS) to $81 \mathrm{Tg}(\mathrm{C}) \mathrm{yr}^{-1}$ (MEGAN2). The range of global monoterpene emissions in literature is 30-128 $\operatorname{Tg}(\mathrm{C}) \mathrm{yr}^{-1}$ (Arneth et al., 2008; Schurgers et al., 2009).

LPJ-GUESS is a dynamic vegetation modelling framework to simulate response of global natural vegetation patterns and ecosystem carbon and water balances to a changing environment. Isoprene and monoterpene production is calculated by adopting the process-based emission algorithm of Niinemets et al. (1999) which infers the effects of temperature and light on emissions from the electron requirement for isoprene production. The model takes into consideration the direct and indirect process-response of BVOC emissions to changing climate and $\mathrm{CO}_{2}$ concentration: leaf BVOC emissions are stimulated in a future environment in response to warmer temperatures, which fosters also leaf photosynthesis rates in most regions. Moreover, warmer temperatures and $\mathrm{CO}_{2}$-fertilisation of photosynthesis lead to enhanced vegetation productivity and leaf area, which also fosters BVOC emissions. At the same time, higher $\mathrm{CO}_{2}$ concentrations are assumed to inhibit production of terpenoids; even though the underlying leaf metabolic mechanism is not yet fully understood, this effect has been observed in a number of studies on isoprene emitting plants (for an overview see Fig. 6 in Arneth et al., 2011). Due to limiting experimental evidence, whether or not a similar response occurs in monoterpene producing species, especially in species that emit from storage, is to date not confirmed.

MEGAN2 is a flexible biogenic emissions modeling framework that estimates emissions of about 150 chemical species, including 41 monoterpenes, from urban, agricultural and wildland ecosystems. The meteorology and landcover controlling variables can be obtained from coupled dynamic models or input from offline sources. Emission capacities can be PFT-based or from gridded maps that account for variations in plant species distributions. For this study, MEGAN2 was run offline using NCAR CCSM3 climate and 

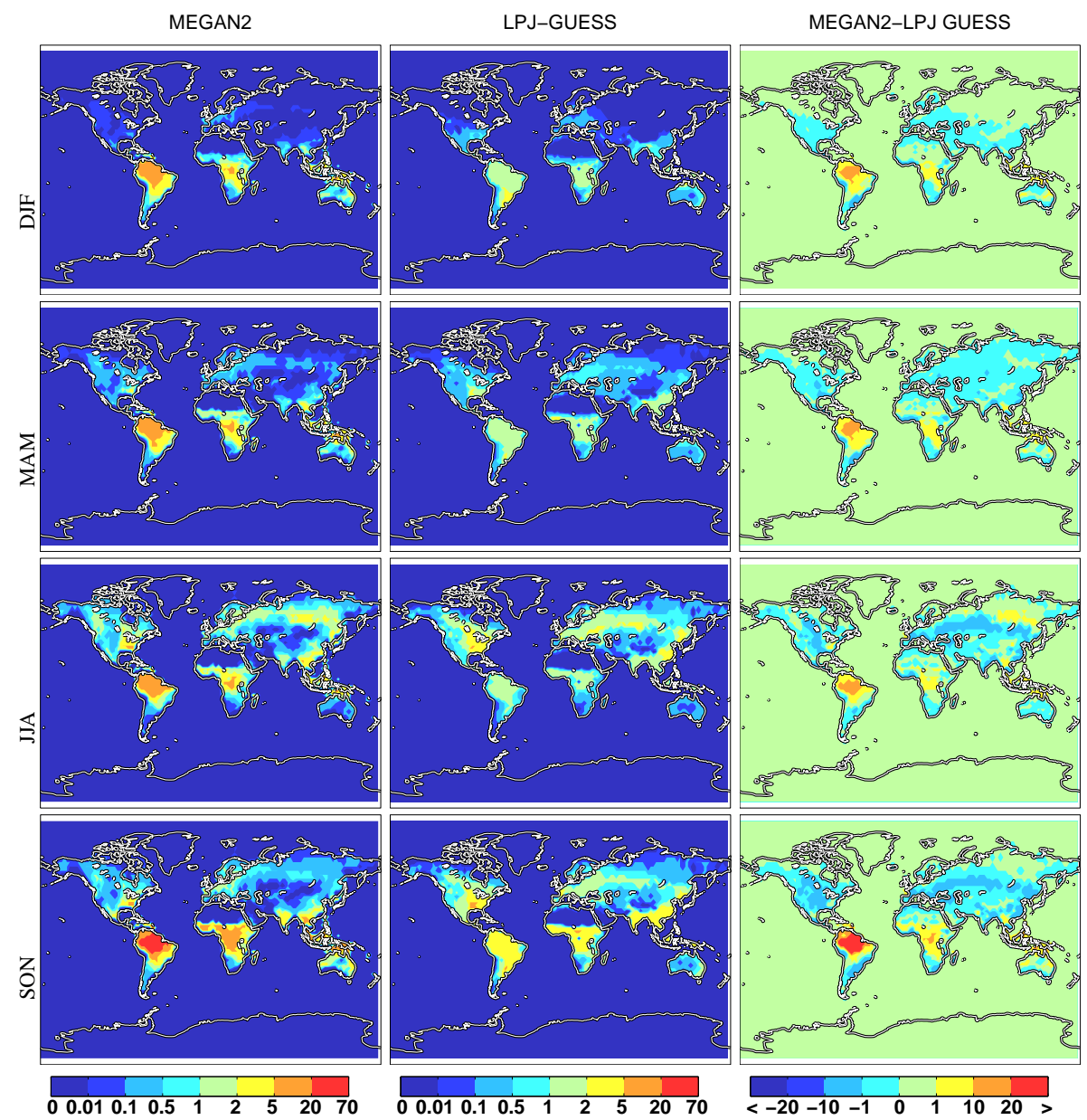

Fig. 1. Monoterpene emission fields from MEGAN2 and LPJ-GUESS models for different seasons $\left(10^{-11} \mathrm{~kg} \mathrm{~m}^{-2} \mathrm{~s}^{-1}\right)$ in the year 2000 . Also shown is the difference of the two models.

satellite observations of landcover (PFT and Leaf Area Index). MEGAN2 isoprene and monoterpene emissions are based on a simple mechanistic model that considers the major processes controlling variations in these emissions. This includes a light response that is based on electron transport and a temperature response based on enzymatic activity (Guenther et al., 1991). MEGAN2 also accounts for the influence of leaf age, soil moisture and the temperature and light environment of the past 2 to 10 days on isoprene and monoterpene emissions (Guenther et al., 2006). The MEGAN2 version used for this study predicts lower global monoterpene emission $\left(81 \mathrm{TgC} \mathrm{yr}^{-1}\right)$ than the earlier MEGAN used with ECHAM5-HAM $\left(127 \mathrm{Tg}(\mathrm{C}) \mathrm{yr}^{-1}\right.$, Stier et al., 2005).

The spatial distributions of the two emission fields shown in Fig. 1 are very dissimilar in the year 2000: MEGAN2 emissions are higher in the tropics and high latitudes, but LPJ-GUESS predicts higher emissions between $25^{\circ} \mathrm{N}$ and $55^{\circ} \mathrm{N}$. It can be seen from Fig. 1 that LPJ-GUESS model predicts higher BVOC emissions over areas with significant anthropogenic emissions. The BVOC emissions from LPJGUESS are even doubled compared to MEGAN2 emissions in areas heavily influenced by fossil fuel and bio-fuel primary emissions. However, in areas dominated by wildfire emissions, MEGAN2 emissions are usually doubled to LPJGUESS emissions. The differences in the spatial correlation of BVOC and anthropogenic emissions affects the sensitivity of $\mathrm{CCN}$ to changes in anthropogenic and natural emissions.

The two models have a distinct behaviour in the timescale from the year 1750 to the year 2100 . The monoterpene emissions in MEGAN2 model respond to the increase in air temperature, resulting in an increase of $+26 \%$ by the year 2100 . In contrast, the LPJ-GUESS model assumes that the leaf foliage responds to the increase in the air temperature and atmospheric $\mathrm{CO}_{2}$ concentration, resulting in a slight net decrease in monoterpene emissions by 2100 . The diverse response of the two BVOC models to climate change and changes in the atmospheric burden of $\mathrm{CO}_{2}$ leads to a factor of 3.5 difference in global monoterpene emission in the year 2100 . 
Table 1. Description of experiments indicating which nucleation mechanisms and BVOC emissions are implemented in each simulation. Not all scenarios are simulated within each experiment. Total number of experiments is 43 , and each experiment is simulated for $5 \mathrm{yr}$.

\begin{tabular}{|c|c|c|c|c|c|c|c|c|c|}
\hline & $\begin{array}{c}\text { Binary } \\
\text { nucleation }\end{array}$ & $\begin{array}{c}\text { Boundary layer } \\
\text { nucleation }\end{array}$ & $\begin{array}{c}\text { MEGAN2/ } \\
\text { LPJ-GUESS }\end{array}$ & 1750 & 2000 & RCP-2.6 & $\begin{array}{c}2100 \\
\text { RCP-4.5 }\end{array}$ & RCP-8.5 & Note \\
\hline BINARY & Yes & - & Yes/Yes & Yes & Yes & Yes & Yes & Yes & \\
\hline SULACT & Yes & Eq. (2) & Yes/Yes & Yes & Yes & Yes & Yes & Yes & \\
\hline ORGSULACT & Yes & Eq. (3) & Yes/Yes & Yes & Yes & Yes & Yes & Yes & \\
\hline ORGSULHET & Yes & Eq. (4) & Yes/No & Yes & Yes & Yes & No & No & \\
\hline SULACT_TER & Yes & Eq. (2) & Yes/No & Yes & Yes & Yes & No & No & No nucleation in MBL \\
\hline ZEROBVOC & Yes & Eq. (2) & $\mathrm{No} / \mathrm{No}$ & No & Yes & No & No & No & No BVOC emission \\
\hline
\end{tabular}

Currently, most global aerosol-climate models prescribe BVOC emissions rather than calculating them interactively. Also, even the current online schemes for BVOC emission calculations do not usually allow for changes in the underlaying assumptions on vegetation or VOC emission strength. One aspect of this paper is to analyze the effect of using two mechanistically different BVOC emission parameterizations on aerosol number concentrations. Since we do not constrain the BVOC emission models with the same meteorology or vegetation, the results shown can also arise from differences in e.g. temperatures, radiation or precipitation. However, this is usually the case when using prescribed emissions in a global aerosol-climate model. In fact, most often models use the BVOC emissions compiled in Guenther et al. (1995), even though the modeled meteorology could be significantly different.

The vegetation distribution and climate used to obtain BVOC emissions are different between MEGAN2 and LPJGUESS. The MEGAN2 model uses NCAR CCSM3 climate model and A2p SRES future scenario corresponding to a $2.1 \mathrm{~K}$ increase in global mean temperature, whereas the LPJGUESS model was driven by HadCM3 climate model with A2 SRES future scenario with a temperature increase of 3.4 K. Rather than SRES scenarios, ECHAM5.5-HAM2 uses the RCP-scenarios to simulate future aerosol concentrations. The differences in the simulated future BVOC emissions are both due to mechanistic differences in the BVOC emission parameterization and the differences in the applied climate scenarios. In this paper, the LPJ-GUESS model was chosen to represent a scenario with rather similar global BVOC emissions in years 2000 and 2100, due to assumed $\mathrm{CO}_{2}$ inhibition. The MEGAN2 model was chosen to represent a scenario with increasing BVOC emissions until the year 2100. Exploring the effects of various climate scenarios on BVOC emission and $\mathrm{CCN}$ is beyond the scope of this paper. It should be noted that the climate in ECHAM5.5-HAM2 is constrained with fixed sea-surface temperatures in all simulations.

An additional present-day sensitivity simulation is conducted with BVOC emissions set to zero, in order to study the effect of BVOC to $\mathrm{OC}$ and $\mathrm{CCN}$ concentrations.

\subsubsection{Other natural emissions}

The emissions of mineral dust, sea salt and DMS are calculated online depending on surface properties and wind speed. Hence, these natural emissions can have a location dependent annual pattern. Also, the natural emissions can change between experiments (pre-industrial, present-day, future) with changing meteorology, although the fixed sea-surface temperature should hold the overall climate in present-day conditions.

Mineral dust is emitted according to Tegen et al. (2002) with modifications by Cheng et al. (2008). We apply the sea salt emission scheme by Guelle et al. (2001). The emissions from continuous and explosive volcanoes are prescribed for present-day conditions in all simulations, according to Stier et al. (2005).

\subsection{Experimental setup}

The simulated experiments are described in Table 1. We will focus on experiments SULACT and ORGSULACT, which are simulated with each anthropogenic emission scenario and both BVOC emission datasets. The ORGSULHET and SULACT_TER simulations are only done using MEGAN2 emissions, to address the increase in future BVOCs. To further reduce the number of simulations, ORGSULHET and SULACT_TER are only simulated with the RCP-2.6 emission scenario (lowest $\mathrm{SO}_{2}$ emission in the year 2100). Results from binary nucleation (BINARY) experiments are presented mainly as a reference, to separate the effect of boundary layer nucleation.

\section{Results and discussion}

In this section we will first show the performance of the model in present-day conditions, together with comparisons to observations. Second, we show the effect of nucleation mechanism and chosen BVOC emission scenario on CCN. Finally, we focus on the effect of nucleation and organics on climate. 

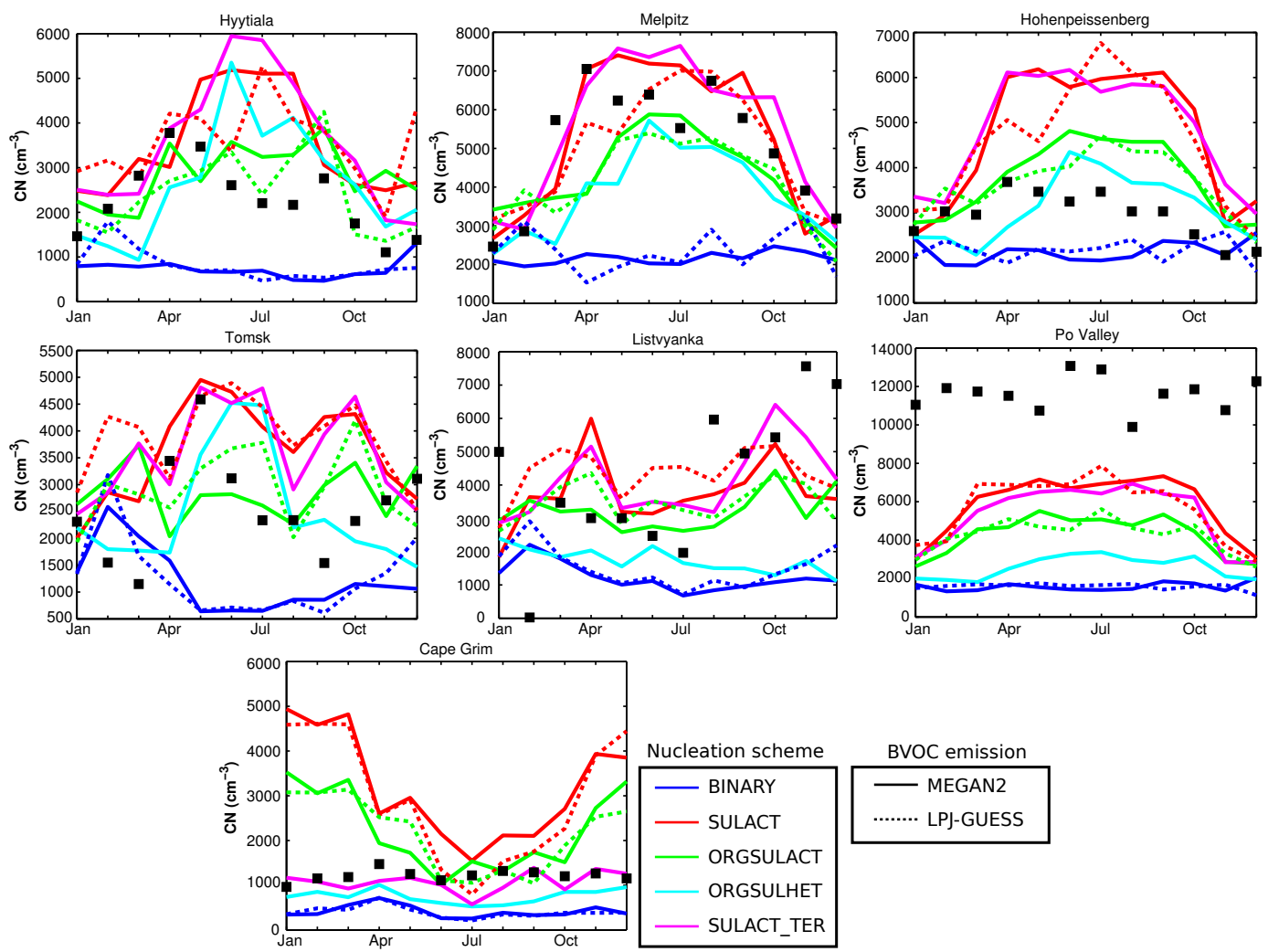

Fig. 2. Comparison of monthly average $\mathrm{CN}$ concentrations $\left(\mathrm{cm}^{-3}\right)$ from model and observations (black squares) at 7 stations. Simulations with different nucleation scheme are separated by color, with solid lines for results with MEGAN2 BVOC emissions and dashed lines for LPJ-GUESS. Observational data is from Spracklen et al. (2010).

Table 2. Annual average $\mathrm{CN}$ concentrations $\left(\mathrm{cm}^{-3}\right)$ at 7 stations. Model results are 5 -yr averages, data coverage of observations varies. Observational data is from Spracklen et al. (2010). The model results closest to observations are emphasized. SMR = Hyytiälä, MPZ = Melpitz, $\mathrm{HPB}=$ Hohenpeissenberg, TMK $=$ Tomsk, LVA $=$ Listvyanka, PVL $=$ Po Valley, CGR = Cape Grim.

\begin{tabular}{lccccccc}
\hline & SMR & MPZ & HPB & TMK & LVA & PVL & CGR \\
\hline Observation & 2299 & 5063 & 2935 & 2542 & 4156 & 11610 & 1215 \\
BINARY & 858 & 2264 & 2136 & 1290 & 1377 & 1584 & 400 \\
SULACT & 3450 & $\mathbf{5 2 5 8}$ & 4744 & 3737 & 3852 & $\mathbf{5 6 6 1}$ & 3156 \\
ORGSULACT & 2830 & 4213 & 3800 & 2795 & 3058 & 4228 & 2129 \\
ORGSULHET & $\mathbf{2 6 1 9}$ & 3857 & $\mathbf{3 1 5 4}$ & $\mathbf{2 6 1 3}$ & 1905 & 2625 & 749 \\
SULACT_TER & 3283 & 5345 & 4705 & 3788 & $\mathbf{4 0 2 9}$ & 5402 & $\mathbf{1 1 1 9}$ \\
\hline
\end{tabular}

\subsection{Comparison of modeled number concentrations to observations}

The model is not nudged against observed meteorology, hence the comparison against field observations is rather qualitative. Still, the model could be expected to produce the observed annual cycle and average concentrations to some extent. The comparison of monthly averages is done against five years of model data and several years of observational data. However, the actual number of observational data for an individual month might be low. Even nudging the model would not render the model exactly to the observed meteorol- ogy, and the nudging can slow down winds (Timmreck and Schulz, 2004). The model uses aerosol and precursor emissions for the year 2000, which are both highly uncertain and might not capture the observed events in several locations. Certain areas might have a strong intra-annual variation in the anthropogenic emissions (due to e.g. heating in wintertime), which is lacking in the model.

Figure 2 and Table 2 show model results for the presentday model experiments compared to 7 sites. The observational data are from Spracklen et al. (2010). In all locations, primary emissions with binary nucleation (BINARY, blue 
Table 3. Normalized mean bias (NMB) and correlation coefficient of monthly average $\mathrm{CN}$ concentrations. Model data is compared to 7 stations shown in Table 2.

\begin{tabular}{lcrcr}
\hline & \multicolumn{2}{c}{ MEGAN2 } & \multicolumn{2}{c}{ LPJ-GUESS } \\
& $R^{2}$ & NMB & $R^{2}$ & NMB \\
\hline BINARY & 0.13 & -59 & 0.19 & -59 \\
SULACT & 0.28 & +38 & 0.25 & +37 \\
ORGSULACT & 0.24 & +4 & 0.22 & +5 \\
ORGSULHET & 0.14 & -24 & - & - \\
SULACT_TER & 0.30 & +13 & - & - \\
\hline
\end{tabular}

lines) produces considerably lower concentrations than the other nucleation mechanisms. Binary nucleation also underestimates the $\mathrm{CN}$ concentrations compared to observations, especially in summertime. All simulations with a boundarylayer nucleation scheme show even 5 to 10 fold higher concentrations compared to simulations with only binary nucleation. Activation-type nucleation including both organics and sulphuric acid (ORGSULACT) produces systematically lower number concentrations than activation nucleation based purely on sulphuric acid (SULACT). This is the result of two factors. Firstly, the activation coefficient for sulphuric acid in ORGSULACT (Eq. 3) is lower than in SULACT (Eq. 2) to compensate for the additional particle formation from organics. Secondly, the organics available for nucleation (see Sect. 2.1.2) are about an order of magnitude lower than the concentrations used in Paasonen et al. (2010), with the exception of Hyytiälä where organics are rather close to observed.

The normalized mean bias (NMB) in Table 3, calculated over $n$ stations as $100 \times \sum_{i=1}^{n}\left(S_{i}-O_{i}\right) / \sum_{i=1}^{n} O_{i}\left(S_{i}\right.$ is the simulated 5-yr average, $O_{i}$ is the observed average), shows that the overall underestimation of $59 \%$ with primary emissions and binary nucleation (BINARY) is replaced by a clear overestimation of $37-38 \%$ with activation-type nucleation by sulphuric acid (SULACT). By turning marine nucleation off (SULACT_TER) has little effect on concentrations at the selected stations with the exception of Cape Grim, where SULACT_TER reduces the NMB to $13 \%$. When organics are taken into account in the nucleation process (ORGSULACT), the NMB over all stations is reduced to $4-5 \%$. With nucleation requiring both sulphuric acid and organics (ORGSULHET), the concentrations are underestimated by $24 \%$.

In addition to underestimating observed $\mathrm{CN}$ concentrations, the combination of binary nucleation and primary emissions is unable to explain the observed seasonal patterns. Figure 2 shows that binary nucleation does not respond to intra-annual variations in precursors, producing a rather flat annual pattern. The underprediction of $\mathrm{CN}$ concentrations in summer months is seen also in Spracklen et al. (2010). Including boundary layer nucleation increases the correlation coefficient $R^{2}$ (Table 3 ) of monthly average concentrations from 0.13-0.19 (BINARY) to 0.25-0.28 with activation-type nucleation by sulphuric acid (SULACT) and to $0.22-0.24$ with organic nucleation (ORGSULACT). The correlations are similar to those found by Spracklen et al. (2010), however our observational dataset is only a subset of that of Spracklen et al. (2010).

In Melpitz, sulphuric acid nucleation (SULACT, monthly $R^{2}=0.83$, annual bias $+4 \%$ ) can explain both the intraannual variation and number concentrations. In Hyytiälä, organic nucleation (ORGSULACT, monthly $R^{2}=0.22$, annual bias $+23 \%$ ) leads to highest correlation coefficient. With the LPJ-GUESS emissions, even the observed July minimum is seen in simulations. In Hohenpeissenberg the sulphuric acid nucleation can explain the intra-annual variation but concentrations are overestimated, possibly by too high modeled sulphuric acid concentrations. In Po Valley the simulations are barely able to produce half of the observed concentration, however, the coarse grid size of the model is not able to capture the orographic features of the site. Perhaps due to lack of sufficient data from Tomsk and Listvyanka, the seasonality of the observations is scattered. Although organic nucleation (ORGSULACT) captures the annual-average concentrations, none of the nucleation schemes can reproduce the monthly variation at these two sites. The only coastal site in the comparison, Cape Grim, shows the effect of turning off MBL nucleation: summertime $\mathrm{CN}$ concentrations are decreased from even 5000 to $1000 \mathrm{~cm}^{-3}$, and the intra-annual profile is flattened. It seems that SULACT_TER actually captures the observed average $\mathrm{CN}$ concentration, but primary emissions and binary nucleation (BINARY) lead to best correlation coefficient, $R^{2}=0.37$.

The effect of the choice of the BVOC emission model on particle number concentrations is the largest in simulations with a boundary layer nucleation scheme, when the organic vapours can influence the growth of newly-formed particles. In simulations with primary emissions and binary nucleation only, the ratio of organic mass in nucleation mode versus organic mass in Aitken mode is about $90 \%$ lower than in simulations with boundary layer nucleation.

As activation-type nucleation by sulphuric acid seems to overpredict particle concentrations rather systematically, it can be speculated whether the modeled sulphuric acid concentrations in ECHAM5-HAM are too high, or whether the activation coefficients in Eq. (2) are too high to be applied globally. This would lead to an overestimation of the sensitivity to changes in sulphuric acid emissions and finally an overestimation of the aerosol indirect forcing. It should also be noted that the scheme for organic aerosols implemented here can not represent the actual state of atmospheric organics. Our model describes organic aerosol as primary, low volatile and non-volatile, without transport or aging of gas-phase organics. Also, we assume that a fraction of monoterpene oxidation products represents the [ORG] in Eqs. (3) and (4), whereas in reality the particle growth rate is not only due to monoterpenes. However, in Hyytiälä the growth rates of 


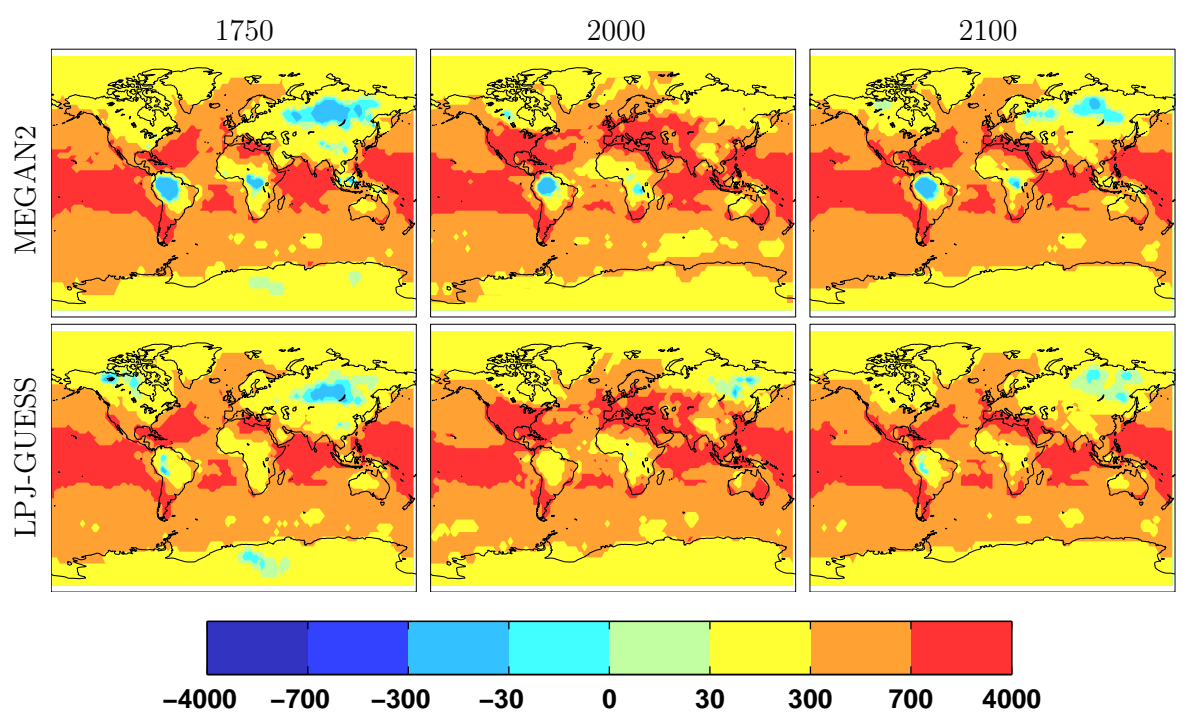

Fig. 3. Effect of nucleation scheme on annual average $\mathrm{CN}$ concentration $\left(\mathrm{cm}^{-3}\right)$ in the year 1750 (left panels), 2000 (center panels) and 2100 (right panels). The maps are calculated as differences CN(SULACT)-CN(ORGSULACT).

7-20 nm particles are clearly correlating with monoterpene concentrations (Yli-Juuti et al., 2011). Altogether, the model could be overestimating the sensitivity of nucleation to sulphuric acid and underestimating the role of other compounds.

The above comparison shows that boundary layer nucleation is needed to explain the $\mathrm{CN}$ concentrations and their annual patterns in ECHAM5.5-HAM2, which is consistent with earlier studies (Spracklen et al., 2010). Organic nucleation (ORGSULACT) seems to produce results closest to observations.

\subsection{Global aerosol fields}

The simulated $\mathrm{CN}$ and $\mathrm{CCN}$ concentrations are shown in the Supplement (Figs. S1-S4). Here we concentrate on the differences in aerosol concentrations arising from different nucleation schemes and BVOC emissions.

\subsubsection{Effect of nucleation on global aerosol fields}

Figure 3 shows the difference fields of $\mathrm{CN}$ concentrations between two different nucleation mechanisms, SULACT and ORGSULACT. Since our model includes no marine BVOC source (and no BVOC transport), the differences in marine nucleation rates between SULACT and ORGSULACT simulations are only due to difference in smaller sulphuric acid activation coefficient in ORGSULACT. This can be seen as an increase in $\mathrm{CN}$ concentration over all marine areas, especially in the tropics. Even with the higher BVOC emissions of MEGAN2, the only areas where organic nucleation produces higher present-day $\mathrm{CN}$ concentration than SULACT are Northern South America, and small patches in central Africa and North America. Due to the intra-annual variation in BVOC emissions, there are also other small areas where
ORGSULACT produces seasonally more particles then SULACT. In the experiments representing future conditions with MEGAN2 emissions, the gap in the total number concentration between SULACT and ORGSULACT is diminishing due to decreasing $\mathrm{SO}_{2}$ and increasing BVOC.

For CCN concentration the differences between SULACT and ORGSULACT are more variable than for CN concentration (Fig. 4). With present-day emissions and MEGAN2 BVOCs, organic nucleation produces more CCN than activation-type nucleation by sulphuric acid only in North America and parts of South America and continental Asia. With LPJ-GUESS emissions, the SULACT nucleation dominates also in North America. The organic nucleation (ORGSULACT) leads to enhanced $\mathrm{CCN}(0.2 \%) / \mathrm{CN}$ ratio: the spatial distribution of nucleated particles is closer to that of growing organic vapours, which increases the probability of a particle to grow to $\mathrm{CCN}$.

Next, let us explore the situation in the marine boundary layer (MBL). Activation-type nucleation by sulphuric acid applied to MBL leads to a significant source of new particles over certain ocean regions, especially in the Western Pacific. This is due to favourable conditions in the top of the boundary layer: a peak in sulphate production from DMS oxidation by $\mathrm{OH}$ and low condensation sink. The spatial distribution of $\mathrm{CN}$ concentration over oceans is similar to that of convective precipitation (Supplement, Fig. S1), indicating the loss of condensation sink due to wet deposition. However, the particles nucleated in the marine boundary layer are not able to grow close to $\mathrm{CCN}$ sizes before they are lost by wet deposition. Since the model is missing a source of marine primary and secondary organics, we might underestimate not only the condensation sink but also the growth of these nucleated particles. Meskhidze et al. (2011) showed that including organic 


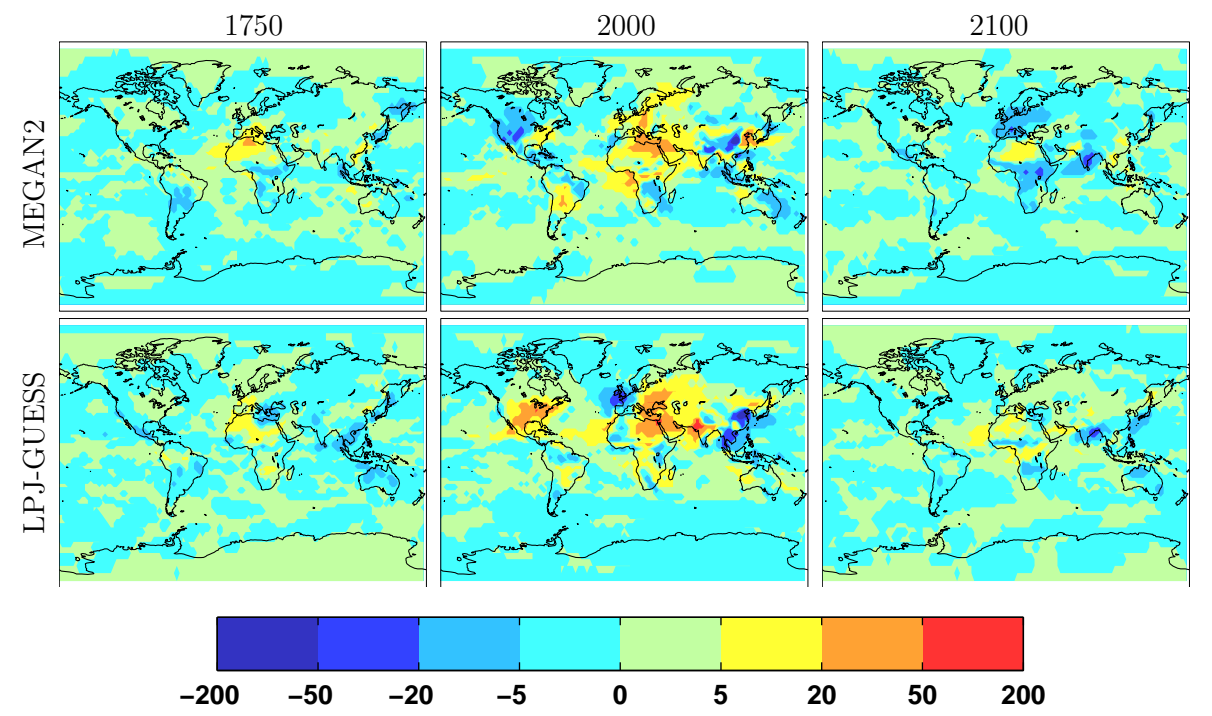

Fig. 4. Effect of nucleation scheme on annual average $\mathrm{CCN}(0.2 \%)$ concentration $\left(\mathrm{cm}^{-3}\right)$ in the year 1750 (left panels), 2000 (center panels) and 2100 (right panels). The maps are calculated as differences CCN(SULACT)-CCN(ORGSULACT).

marine sources could increase the global average $\mathrm{CCN}$ over oceans from +4.0 to $+4.6 \%$. A very limited number of observations of sub-10 nanometer particles from the marine boundary layer exists, which makes it difficult to evaluate model results or to discard any processses.

We also explored the sensitivity to MBL nucleation with an experiment SULACT_TER, where boundary layer nucleation is switched off from over oceans. The spatial CCN distributions in SULACT and SULACT_TER look similar (Supplement Fig. S3), but as modeled CCN values over oceans are small compared to continental regions, there are areas where the marine nucleation leads to an increase in $\mathrm{CCN}$ by 20 $40 \%$. The global average $\mathrm{CCN}(0.2 \%)$ over oceans increases from 93 to $100 \mathrm{~cm}^{-3}$ (8\%) due to marine nucleation. However, the spatial distribution of the $\mathrm{CCN}$ increase due to nucleation is rather different from that due to marine organic emissions (Meskhidze et al., 2011), since nucleation prefers areas of low condensation sink while marine organic emissions correlate with biogenic activity.

Langley et al. (2010) present number concentrations for July from the Northeast Pacific, showing a mean $\mathrm{CN}\left(d_{\mathrm{p}}<\right.$ $300 \mathrm{~nm})$ concentration of $500 \mathrm{~cm}^{-3}$ and $\mathrm{CCN}(0.19 \%)$ concentrations ranging from 27 to $360 \mathrm{~cm}^{-3}$. Our model simulations suggest that activation-type nucleation by sulphuric acid (SULACT) and even the lower activation coefficients in ORGSULACT produce too many particles in the MBL, with monthly average $\mathrm{CN}$ concentrations of $2138 \mathrm{~cm}^{-3}$ and $1414 \mathrm{~cm}^{-3}$, respectively. However, it is clear that the simulation without any nucleation in the MBL is unable to capture the $\mathrm{CN}$ concentration, resulting in an average of $169 \mathrm{~cm}^{-3}$. Also, none of our simulations can reproduce the observed range of $\mathrm{CCN}(0.2 \%)$ concentrations in the MBL, as the monthly averages range from $22 \mathrm{~cm}^{-3}$ (MBL nucleation off) to $27 \mathrm{~cm}^{-3}$ (MBL nucleation on). Langley et al. (2010) conclude that the biogenic marine organics are of minor importance in the study region, and the CCN concentration correlates well with sulphate plus methanesulphonic acid (MSA).

\subsubsection{Effect of BVOC scheme on global aerosol fields}

Figure 5 shows the effect of BVOC emission scenario on CCN concentrations. Compared to LPJ-GUESS emissions, the MEGAN2 BVOC emissions lead to increased presentday CCN in the tropical South America, major parts of Africa, Southeast Asia, Oceania and some boreal forest regions. When considering organic nucleation, $\mathrm{CCN}$ concentrations with MEGAN2 are higher also in North America. The CCN differences emerging from the two different BVOC models are consistent with the spatial emission patterns shown in Fig. 1, with the exception of organic nucleation results in North America, where LPJ-GUESS shows more BVOC emissions. The MEGAN2 emissions are increasing the $\mathrm{CCN}(0.2 \%) / \mathrm{CN}$ ratio in the tropics and northern hemisphere high latitudes.

Figure 6 shows histograms of $\mathrm{CN}$ and $\mathrm{CCN}$ concentrations as a function of monoterpene emission, calculated separately for monthly averages over each grid box. The results are from ORGSULACT simulations with MEGAN2 (left panels) and LPJ-GUESS (right panels) emissions. High monoterpene emissions correlate positively with high $\mathrm{CCN}$ concentrations (more pronounced with MEGAN2 emissions), which can be a result of both increased growth of sub-CCN particles and co-incidental increase in primary emissions (e.g. wild-land fires). When moving from higher to lower biogenic emissions, the $\mathrm{CCN}$ concentrations are clearly separated into 


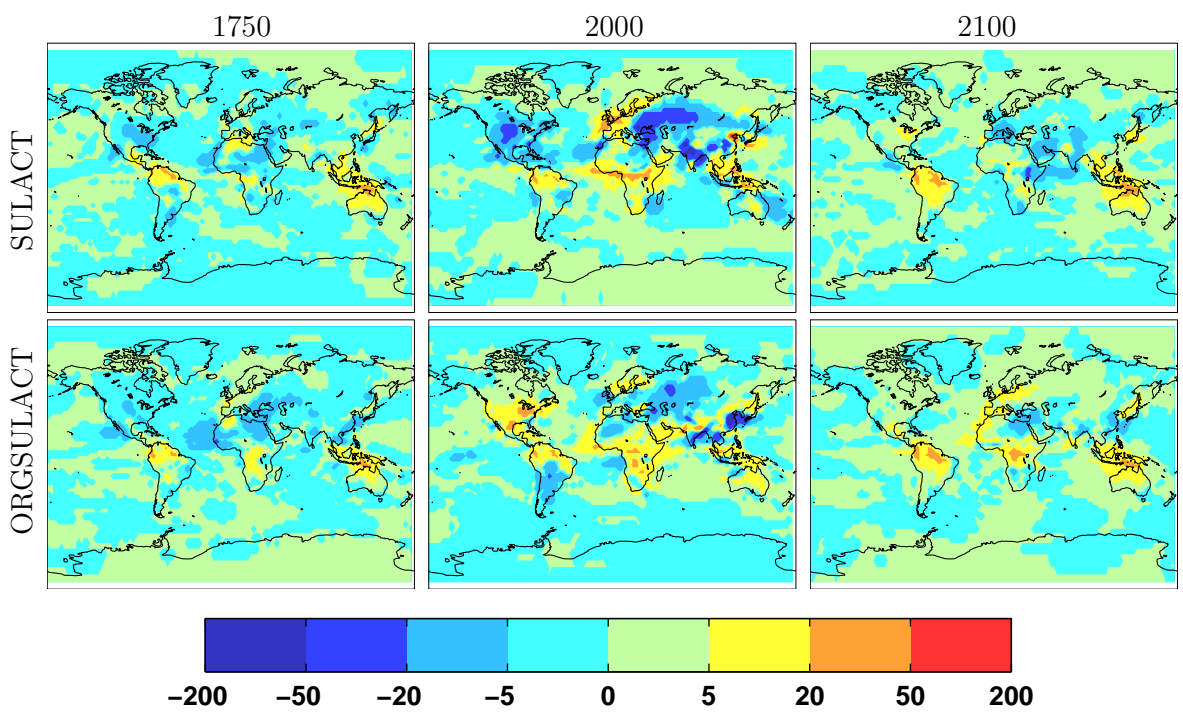

Fig. 5. Effect of BVOC emission scheme on annual average $\mathrm{CCN}(0.2 \%)$ concentration $\left(\mathrm{cm}^{-3}\right)$ in the year 1750 (left panels), 2000 (center panels) and 2100 (right panels). The maps are calculated as differences CCN(MEGAN2)-CCN(LPJ-GUESS).

areas of low $\left(0.1-10 \mathrm{~cm}^{-3}\right)$ and high $\left(100-1000 \mathrm{~cm}^{-3}\right) \mathrm{CCN}$ concentration.

With MEGAN2 emissions, the relation between monoterpene emission and $\mathrm{CN}$ concentration shows a positive correlation when the monoterpene emissions are low $\left(10^{-15}-\right.$ $10^{-12} \mathrm{~kg} \mathrm{~m}^{-2} \mathrm{~s}^{-1}$, and a negative correlation at higher emissions $\left(>10^{-12} \mathrm{~kg} \mathrm{~m}^{-2} \mathrm{~s}^{-1}\right.$ ). The anticorrelation at high emission locations can be due to increase in condensation sink, leading to decreased nucleation rates.

\subsection{Evolution of the regional composition of aerosols}

Five regions (Asia, Europe, North America, South America and Siberia, Fig. 7) were selected to analyze the regional differences in the evolution of aerosol composition, and their relation to $\mathrm{CCN}(0.2 \%)$ concentration. Figure 8 shows the total $\mathrm{OC}, \mathrm{BC}$ and $\mathrm{SO}_{4}$ mass concentrations in these regions. We only consider land points of the selected regions. The concentrations shown in Fig. 8 are averaged from SULACT simulations. To highlight the influence of SOA formation, results from MEGAN2 and LPJ-GUESS are shown separately. Also results from present-day simulations with zero BVOC emissions is included.

Changes in cloud properties due to BVOC emissions can induce changes in $\mathrm{BC}$ and $\mathrm{SO}_{4}$ concentrations via altered wet deposition fluxes. Also, changes in cloudiness can affect the in-cloud production of $\mathrm{SO}_{4}$. The results in Fig. 8 are averaged over five years to smoothen the noise arising from these indirect effects on aerosol composition.

Common to all regions, the anthropogenic influence on $\mathrm{SO}_{4}$ concentrations is diminishing by the year 2100 , although some variation is seen between the different future emission pathways. In general, future $\mathrm{BC}$ concentrations are decreasing from the present-day levels, but not so much as $\mathrm{SO}_{4}$ concentrations. Also, the future emission pathways induce more variation in the $\mathrm{BC}$ concentrations. Finally, the evolution of the OC concentrations shows significant variation, ranging from a decrease to pre-industrial levels by the year 2100 , or even an increase from present-day concentration levels. It should be noted that the we do not apply any intra-annual variation in the anthropogenic emissions.

\subsubsection{Asia}

In Asia, wildfire emissions peak during the spring: in February-April in the year 2000, and in March in the years 1750 and 2100. Only during the spring, wildfire emissions dominate the $\mathrm{OC}$ and $\mathrm{BC}$ concentration over fossil and biofuels. In the future scenarios used here, the wildfire emissions will either stay near present-day levels (RCP-2.6), decrease slightly (RCP-8.5) or decrease close to pre-industrial levels (RCP-4.5). All future pathways show a strong reduction in biofuel emissions, even up to $90 \%$, while the reduction in fossil fuel emissions varies from 25 to $70 \%$. The effect of biogenic SOA is tampered by the increased deposition in the rainy season. The present-day regional average monoterpene emissions of MEGAN2 and LPJ-GUESS are similar in Asia. However, in the year 2100, the summertime monoterpene emissions of MEGAN2 are up to 30$40 \%$ higher than those of LPJ-GUESS. Enhanced future BSOA formation can be seen as a difference in the OC concentrations between MEGAN2 and LPJ-GUESS. Although the contribution of biogenic SOA to total OA is increased in the future, the difference in $\mathrm{CCN}$ concentration between MEGAN2 and LPJ-GUESS is almost indistinguishable in Fig. 8. The BVOC emissions of LPJ-GUESS are higher than 

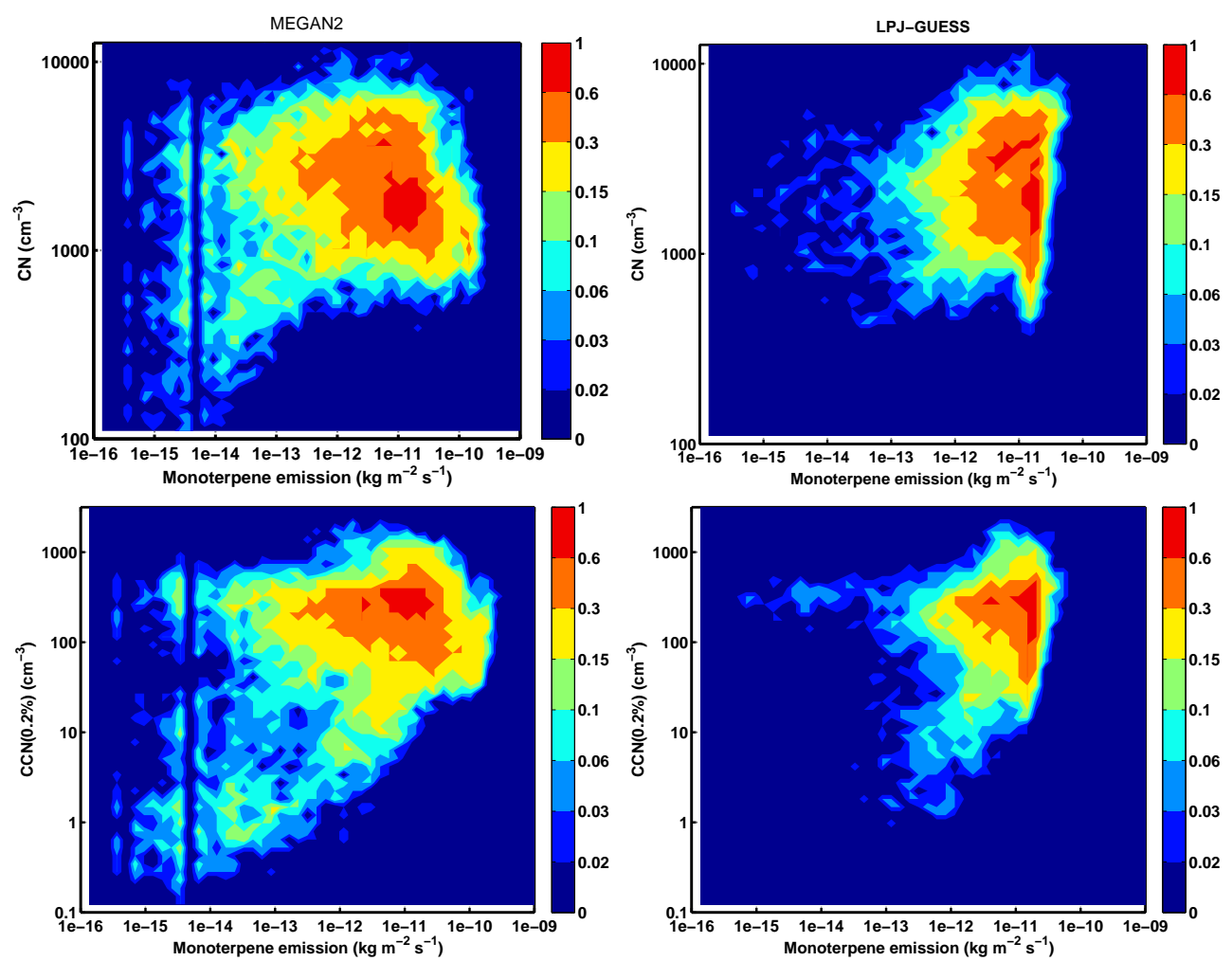

Fig. 6. 2-D histograms (density plots) of the monoterpene emission (x-axis) versus $\mathrm{CN}$ concentration (upper panels) and $\mathrm{CCN}(0.2 \%)$ concentration (lower panels) from ORGSULACT simulations. The histograms are calculated from monthly averages for each model grid box over land surface and the maximum value is scaled to unity. Surface level aerosol number concentrations are calculated from $5 \mathrm{yr}$ of model simulation.

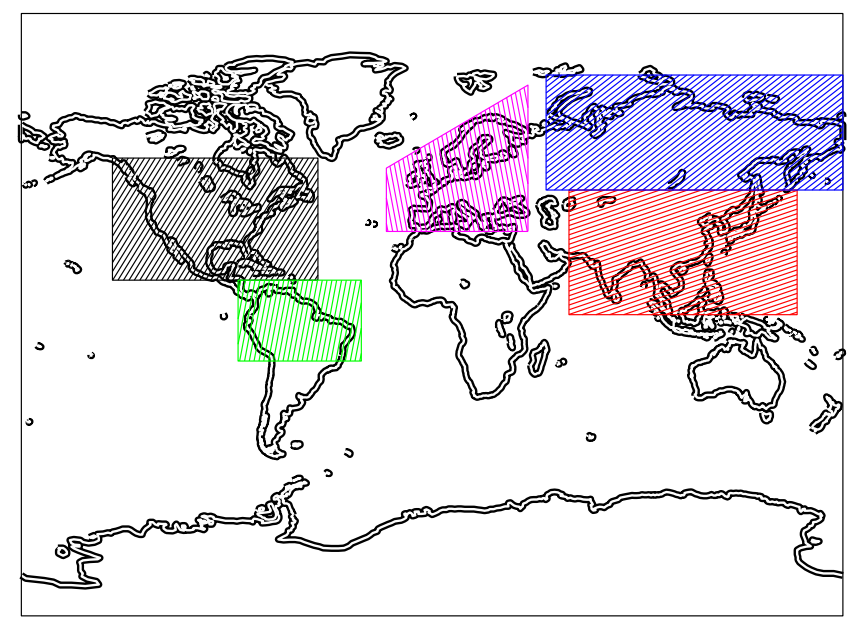

Fig. 7. Regions used for analysis in Fig. 8: Europe (purple), Siberia (blue), Asia (red), South America (green), North America (black).
MEGAN2 emissions in many areas with high $\mathrm{CN}$ concentration, leading to efficient conversion of $\mathrm{CN}$ to $\mathrm{CCN}$.

\subsubsection{Siberia}

In Siberia, the majority of $\mathrm{OC}$ and $\mathrm{BC}$ concentrations can be explained by wildfire emissions, with some contribution to OC from the biogenic SOA formation. The Siberian monoterpene emissions peak in July, independent of the BVOC emission model or simulated year. In the year 1750 , the emission from wildfires were high in July-August, and together with the SOA emission, the wildfire emission explain the intra-annual variation of $\mathrm{OC}$ and $\mathrm{BC}$. There is some timeshift in wildfire emissions when moving to presentday conditions, with maximum emissions reached already in June, resulting in a widened and shifted OC concentration. While the wintertime $\mathrm{BC}$ concentrations were close to zero in the year 1750, the present-day anthropogenic emissions shift the minimum $\mathrm{BC}$ concentration to about $0.02 \mu \mathrm{g} \mathrm{m}^{-3}$. The $90 \%$ reduction in Siberian biofuel and fossil fuel emissions until the year 2100 brings the wintertime $\mathrm{BC}$ concentrations close to zero. Interestingly, the $\mathrm{OC}$ and $\mathrm{BC}$ concentrations show two peaks in the year 2100, in May and July-August. The July-August maximum coincides with the pre-industrial 

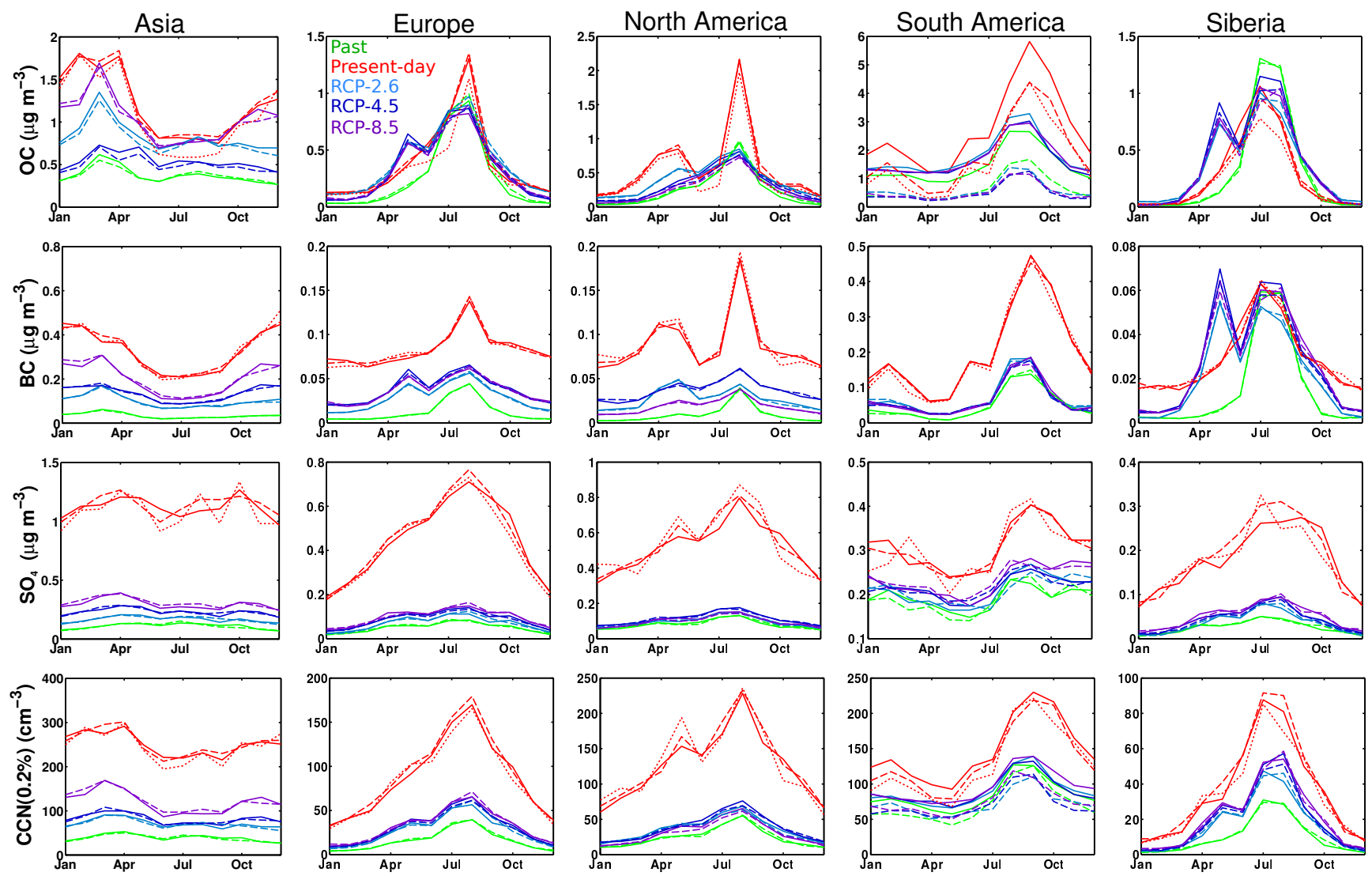

Fig. 8. Monthly average concentrations of $\mathrm{OC}, \mathrm{BC}, \mathrm{SO}_{4}\left(\mu \mathrm{g} \mathrm{m}^{-3}\right)$ and $\mathrm{CCN}(0.2 \%)\left(\mathrm{cm}^{-3}\right)$ in 5 areas defined in Fig. 7. Color indicates the time period: 1750 (green), 2000 (red) and 2100 (RCP-2.6 = light blue, RCP-4.5 = dark blue, RCP-8.5= magenta). BVOC emissions of MEGAN2 (solid lines) and LPJ-GUESS (dashed lines) are plotted separately. For present-day, the results from zero BVOC emission simulation are shown (dotted red line). To ease the readibility, the scale on the y-axis varies between different panels.

intra-annual pattern, and is a result of wildfire and monoterpene emissions. The sharp peak in May is purely from wildfire emissions, and can be seen in all future pathways. The monoterpene emissions of MEGAN2 are somewhat higher than those of LPJ-GUESS in June-July, however the LPJGUESS shows more monoterpene emissions in spring and autumn. The region is characterized by lowest continental $\mathrm{CCN}$ concentrations, with summertime values peaking at only $30 \mathrm{~cm}^{-3}$ in the pre-industrial. The anthropogenic emissions increase the present-day maximum $\mathrm{CCN}$ concentration to about $90 \mathrm{~cm}^{-3}$, and the contribution from BVOCs can be even $20 \%$.

\subsubsection{Europe}

Europe and Siberia have rather similar monthly patterns for $\mathrm{OC}$ and $\mathrm{SO}_{4}$, although concentrations of $\mathrm{SO}_{4}$ over Europe are roughly twice those in Siberia. The July-August maximum in the OC concentration is due to biogenic and wildfire emissions. Both wildfire and monoterpene emissions show an increase until the year 2100. The peak in springtime OC concentrations reflects the future increase in wildfire emis- sions, but the summertime OC concentrations are decreasing due to anthropogenic emission reductions. The future $\mathrm{SO}_{4}$ concentrations are decreased close to pre-industrial values, with even $80 \%$ reductions in summertime. Overall, the different future pathways lead to very little variation in $\mathrm{OC}$, $\mathrm{BC}$ and $\mathrm{SO}_{4}$ concentrations. MEGAN2 shows more BVOC emissions in the Northern Europe, whereas LPJ-GUESS emissions are generally stronger in the Southern Europe. On average, BVOC emissions increase the summertime $\mathrm{CCN}$ by $5-10 \%$.

\subsubsection{South America}

The majority of present-day $\mathrm{SO}_{2}$ emissions in South America are from natural sources (volcanoes and wildfires), and the wildfire emissions have tripled since the pre-industrial. From the five selected regions, South America shows the highest OC concentrations. The region is limited to the northern part of South America $\left(15^{\circ} \mathrm{N}-20^{\circ} \mathrm{S}\right)$ to highlight the difference in the monoterpene emissions from MEGAN2 and LPJ-GUESS: the present-day monoterpene emissions of MEGAN2 are more than 5 times higher than those of 
Table 4. Annual average $\mathrm{CN}, \mathrm{CCN}(0.2 \%)$ and cloud droplet number concentrations from all experiments. The $\mathrm{CN}$ and $\mathrm{CCN}(0.2 \%)$ concentrations are averages over $460-1100 \mathrm{~m}$ above surface layer, and CDNC is averaged over $0-2 \mathrm{~km}$.

\begin{tabular}{ll|c|c|ccc}
\hline $\begin{array}{l}\text { Nucleation } \\
\text { mechanism }\end{array}$ & $\begin{array}{l}\text { BVOC } \\
\text { emission }\end{array}$ & Year 1750 & Year 2000 & \multicolumn{2}{c}{$\begin{array}{c}\text { Year 2100 } \\
\text { RCP-4.5 }\end{array}$} \\
\hline \multirow{2}{*}{ BINARY } & MEGAN2 & $388-47-56$ & $516-95-83$ & $447-58-61$ & $441-60-61$ \\
& LPJ-GUESS & $391-46-56$ & $515-95-83$ & $448-57-61$ & $445-59-62$ & $470-63-64$ \\
RULACT & MEGAN2 & $1969-57-79$ & $2176-113-110$ & $2002-67-83$ & $2092-70-85$ & $2087-75-88$ \\
& LPJ-GUESS & $1971-55-78$ & $2172-111-109$ & $2005-66-83$ & $2088-67-84$ & $2092-72-87$ \\
ORGSULACT & MEGAN2 & $1517-56-76$ & $1670-111-106$ & $1546-67-81$ & $1608-69-82$ & $1610-74-86$ \\
CPJ-GUESS & $1510-55-77$ & $1658-108-106$ & $1528-64-80$ & $1601-66-81$ & $1596-71-85$ \\
ORGSULHET & MEGAN2 & $804-51-63$ & $931-103-93$ & $868-62-67$ & - & - \\
SULACT_TER & MEGAN2 & $826-52-63$ & $1093-107-95$ & $889-62-68$ & - & - \\
\hline
\end{tabular}

LPJ-GUESS, and the difference is even stronger in the year 2100. The effect of the higher SOA production is seen in the OC concentrations, with $0.7-1.5 \mu \mathrm{g} \mathrm{m}^{-3}$ higher concentrations from MEGAN2 than from LPJ-GUESS in the years 1750 and 2000, and $>1 \mu \mathrm{g} \mathrm{m}^{-3}$ in the year 2100. The effect of higher monoterpene emission of MEGAN2 on the CCN concentration is visible in the present-day, and future conditions with even higher biogenic emissions lead to a difference of $10-30 \mathrm{~cm}^{-3}$ in CCN concentration between MEGAN2 and LPJ-GUESS.

\subsubsection{North America}

The region of North America is characterized by a high OC concentration peak in August, arising from overlapping wildfire emissions and biogenic SOA formation. Wildfire emissions are even higher during April-May in present-day conditions, but the springtime concentration peak is more subtle due to higher deposition rates. As seen in Fig. 1, LPJGUESS estimates generally more monoterpene emissions in this region, which can also be seen as higher $\mathrm{CCN}$ concentration with LPJ-GUESS. Anthropogenic emissions establish a background BC concentration of $0.2 \mu \mathrm{g} \mathrm{m}^{-3}$, which is modulated by wildfire emissions in spring and late summer. The present-day $\mathrm{SO}_{2}$ emissions are dominated by power generation and industrial sources.

\subsection{Global aerosol number concentrations}

Table 4 summarizes simulated global average concentrations of $\mathrm{CN}, \mathrm{CCN}$ and cloud droplet number. Activation-type nucleation by sulphuric acid (SULACT) and MEGAN2 emission leads to highest $\mathrm{CCN}$ concentrations in all the experiments. Comparing SULACT and ORGSULACT simulations, the differences in $\mathrm{CCN}$ concentrations due to the nucleation scheme are of similar magnitude as differences due to the BVOC scheme.

Compared to LPJ-GUESS, the higher BVOC emissions of MEGAN2 provide more growth for existing particles and, in the case of organic nucleation (ORGSULACT), increased nucleation rates. The effect of BVOC emission scheme on globally averaged total aerosol number concentrations is rather small. However, in simulations with organic nucleation, the MEGAN2 emissions lead to $0.5-1 \%$ more $\mathrm{CN}$ than simulations with LPJ-GUESS emissions.

The higher particle growth rates with MEGAN2 increase the likelyhood of small particles to reach CCN sizes. Our simulations show that the ratio $\mathrm{CCN}(0.2 \%) / \mathrm{CN}$ is increased globally by $0-5 \%$ with MEGAN2 emissions, compared to simulations with LPJ-GUESS emissions. The increase of the ratio $\mathrm{CCN}(0.2 \%) / \mathrm{CN}$ is more pronounced with boundary layer nucleation (ORGSULACT and SULACT), as the spatial distribution of nucleated particles is more correlated with BVOC emissions than in simulations with only binary nucleation.

Simulations using MEGAN2 BVOC emissions always lead to higher global average $\mathrm{CCN}(0.2 \%)$ concentration compared to simulations using LPJ-GUESS BVOC emissions. In the present-day, MEGAN2 leads to 2-3\% higher $\mathrm{CCN}(0.2 \%)$ concentration than LPJ-GUESS, depending on the boundary layer nucleation scheme. The difference in the two BVOC emission scenarios increases until the year 2100, as MEGAN2 predicts an increase in BVOC due to warmer climate and LPJ-GUESS a slight decrease due to $\mathrm{CO}_{2}$ inhibition. This results in a $3-5 \%$ difference in the $\operatorname{CCN}(0.2 \%)$ concentration between MEGAN2 and LPJ-GUESS in the year 2100. Increased availability of condensable organics has less effect ( $2 \%$ ) on CCN concentration in simulations having only binary nucleation, since most of the boundary layer particles are from primary emissions and already close to the CCN sizes.

With activation-type nucleation by sulphuric acid (SULACT) and LPJ-GUESS emissions for BVOC, the decrease in $\mathrm{CCN}(0.2 \%)$ concentration from present-day to the year 2100 ranges from 35 to $41 \%$. Using MEGAN2 BVOC emissions with an increase of BVOCs by 2100 , the decrease in $\mathrm{CCN}$ is weakened, and ranges from 34 to $40 \%$. Similarly with organic nucleation, MEGAN2 BVOC emissions weaken the CCN concentration decrease from $34-40 \%$ (as 


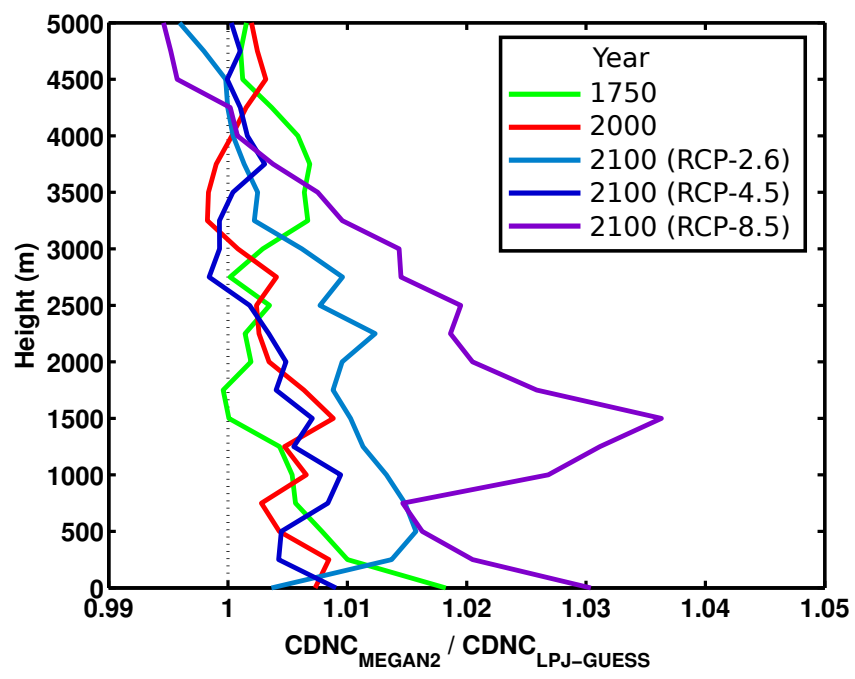

Fig. 9. Vertical profiles of global average CDNC ratio with BVOC emissions from MEGAN2 and LPJ-GUESS, calculated as $\mathrm{CDNC}_{\text {MEGAN2}} / \mathrm{CDNC}_{\mathrm{LPJ}-G U E S S}$. Results are averaged over the SULACT and ORGSULACT experiments.

simulated with LPJ-GUESS) to 33-39\%. The increase in future BVOC emission moderates the loss in CCN concentration between the years 2000 and 2100, being indicative of the effect of the BVOC-aerosol feedback.

In the study by Wang and Penner (2009), binary nucleation together with primary emissions produced a $\mathrm{CCN}(0.2 \%)$ concentration of $160 \mathrm{~cm}^{-3}$, while the addition of activationtype nucleation increased the $\mathrm{CCN}(0.2 \%)$ concentration to $169 \mathrm{~cm}^{-3}(+6 \%)$. Pierce and Adams (2009) found a $12 \%$ variation in boundary layer $\mathrm{CCN}(0.2 \%)$ concentration due to nucleation parameterizations. Our simulations show a slightly higher sensitivity of $18-19 \%$ to including boundary nucleation.

While the continental $\mathrm{CCN}(1.0 \%)$ concentrations simulated in this study are similar to those found by Merikanto et al. (2009), the continental $\mathrm{CCN}(0.2 \%)$ concentration of $197 \mathrm{~cm}^{-3}$ from our simulations is less than half of the $461 \mathrm{~cm}^{-3}$ in Merikanto et al. (2009). The mismatch in $\mathrm{CCN}(0.2 \%)$ concentrations could indicate less effective particle growth in our model, or a numerical difficulty of obtaining $\mathrm{CCN}(0.2 \%)$ concentration from the modal setup of our model: the activation radii for the supersaturation of $0.2 \%$ lies often in the tail of the Aitken mode, hence integrating $\mathrm{CCN}(0.2 \%)$ includes the concentration minimum between Aitken and accumulation modes.

\subsection{Cloud properties and radiative forcings}

\subsubsection{Cloud droplet number concentrations}

Figure 9 shows the vertical variation in the CDNC ratio with the two BVOC emission schemes. Below $2 \mathrm{~km}$ height, MEGAN2 emissions lead to higher global average CDNC than LPJ-GUESS emissions. The CDNC averaged over 0$2 \mathrm{~km}$ height are shown in Table 4. The differences in CDNC caused by the two BVOC emission scenarios are small in the years 1750 and 2000, although MEGAN2 tends to lead to higher concentrations. In the future, MEGAN2 emissions lead to 1-2\% higher global average CDNC between the surface and $2000 \mathrm{~m}$ altitude, compared to LPJ-GUESS. Generally, the increase in CDNC is more pronounced with organic nucleation, when the BVOCs have a direct effect on number concentrations.

Including boundary layer nucleation in the model increases CDNC by $11-42 \%$, compared to simulations with binary nucleation only. Activation-type nucleation by sulphuric acid (SULACT) leads to highest concentrations, predicting 2-4\% more CDNC than organic nucleation (ORGSULACT) in all time periods.

The global average CCN concentration is sometimes used to draw rather direct conclusions on the cloud properties, but as indicated in Table 4, different CCN perturbations have variable effects on CDNC. We define a ratio $R_{\text {act }}=\mathrm{CDNC} / \mathrm{CCN}(0.2 \%)$ to indicate the fraction of $\mathrm{CCN}(0.2 \%)$ that makes cloud droplets. It should be noted that the concentrations are averaged very differently: $\mathrm{CCN}(0.2 \%)$ is averaged over the whole globe at an altitude of $460-1100 \mathrm{~m}$, whereas the CDNC is sampled only from cloudy grid boxes. A minimum CDNC of $20 \mathrm{~cm}^{-3}$ is used in ECHAM5.5-HAM2 if a cloud is formed in a model grid box with a low particle number concentration.

The ratio $R_{\text {act }}$ varies significantly between the time periods: a decrease from 1.2-1.4 in the pre-industrial to $0.9-1.0$ in the present-day, rising to $1.0-1.3$ until the year 2100 . The SULACT experiments are slightly $(0-2 \%)$ more effective than ORGSULACT in producing CDNC from $\mathrm{CCN}(0.2 \%)$. While nucleation has only a marginal effect on $R_{\text {act }}$, the MEGAN2 BVOC emissions lead to 1-4\% smaller $R_{\text {act }}$ than LPJ-GUESS emissions. Still, the $R_{\text {act }}$ is mostly defined by the simulated time period (pre-industrial, present-day, future). While the global CDNC in year 2100 are close to preindustrial values, the future $\mathrm{CCN}$ concentrations can be even $37 \%$ higher than pre-industrial.

\subsubsection{Changes in cloud albedo and forcing}

The low CDNC in simulations without boundary layer nucleation (BINARY) lead to larger changes the cloud albedo $(\triangle \mathrm{Rc})$ than observed in the SULACT and ORGSULACT simulations (Table 5). Similar results were shown by Merikanto et al. (2010), where the change in cloud albedo from the year 1850 to the year 2000 was found to be $+3.97 \%$ and $+3.85 \%$ without and with boundary layer nucleation, respectively. Due to overall lower simulated CDNC compared to Merikanto et al. (2010) (who reported CDNC at altitude $300-1000 \mathrm{~m}$ ), our cloud albedo changes are more sensitive to the addition of boundary nucleation scheme (change in cloud albedo from pre-industrial to present-day $>+4.42 \%$ ). 


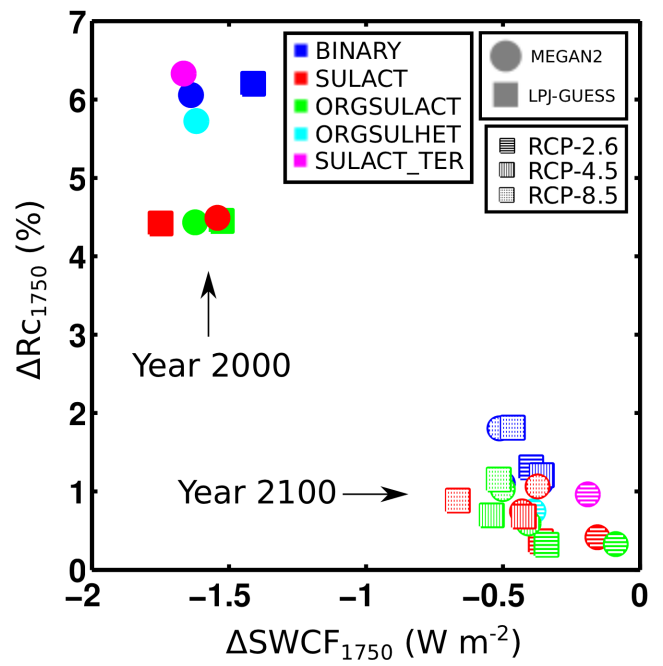

Fig. 10. Change in the cloud forcing $\Delta \mathrm{SWCF}_{1750}\left(\mathrm{~W} \mathrm{~m}^{-2}\right)$ plotted against the change to cloud albedo $\Delta \operatorname{Rc}_{1750}(\%)$. Changes are relative to the year 1750 .

The reduction of the cloud albedo forcing (1st indirect effect) due to boundary layer nucleation was also observed by Wang and Penner (2009). The largest $\Delta \mathrm{Rc}$ for both presentday and future is found in SULACT_TER simulations, in which the aerosol concentrations are highly sensitive to the anthropogenic emissions, but the natural background aerosol concentrations over oceans are lower.

Considering only the main experiments SULACT and ORGSULACT, the decrease in the cloud albedo from the year 2000 to the year 2100 is $4.1 \%, 3.8 \%$ and $3.4 \%$ with emission pathways RCP-2.6, RCP-4.5 and RCP-8.5, respectively. Averaged over all future pathways, MEGAN2 and LPJ-GUESS emissions lead to a similar change in cloud albedo $(-3.8 \%)$.

Figure 10 shows the change in shortwave cloud forcing $\left(\triangle \mathrm{SWCF}_{1750)}\right)$ and the corresponding change in the cloud albedo $\left(\Delta \mathrm{Rc}_{1750}\right)$, calculated relative to pre-industrial conditions. The correlation between $\Delta \mathrm{SWCF}_{1750}$ and $\Delta \mathrm{Rc}_{1750}$ indicates that the albedo change calculated in Eq. (1) is a good indicator for changes in the cloud radiative effect. There is a clear separation between the present-day and future conditions, whereas the model results for same time period are rather similar. $\triangle \mathrm{SWCF}_{1750}$ ranges from -1.4 to $-1.7 \mathrm{~W} \mathrm{~m}^{-2}$ with an average of $-1.6 \mathrm{~W} \mathrm{~m}^{-2}$ in the year 2000 , and from -0.1 to $-0.7 \mathrm{~W} \mathrm{~m}^{-2}$ with an average of $-0.4 \mathrm{~W} \mathrm{~m}^{-2}$ in the year 2100 . The average changes in the cloud forcing and cloud albedo from the present-day to the year 2100 are $+1.2 \mathrm{~W} \mathrm{~m}^{-2}$ and $-4.2 \%$, respectively.

Figure 11 shows that the low-cloud cover, ranging from 31.6 to $32.4 \%$, is clearly connected to the CCN concentration in our simulations. The sensitivity of low-cloud cover to $\mathrm{CCN}$ concentrations is the highest in the pre-industrial and lowest in the present-day conditions. As shown in Table 5,

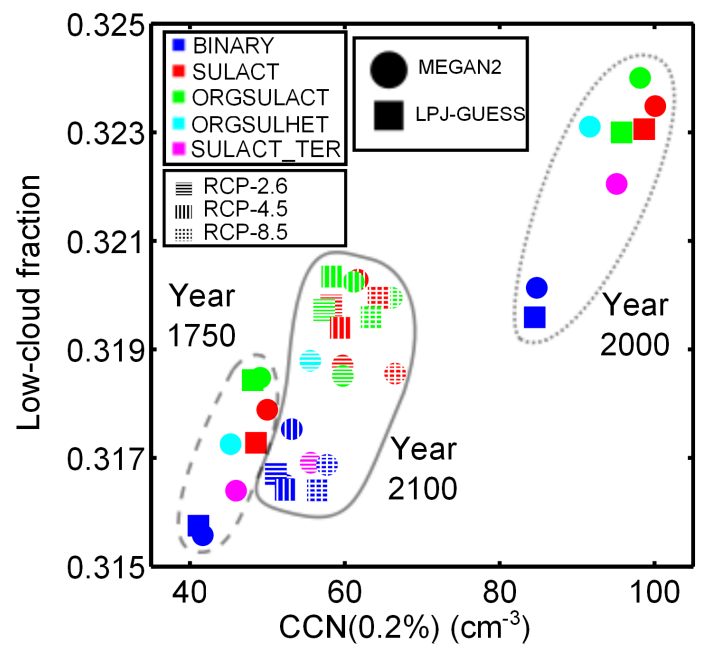

Fig. 11. Global average $\mathrm{CCN}(0.2 \%)\left(\mathrm{cm}^{-3}\right)$ versus global average low-cloud fraction from all simulations and time periods. Grey lines are drawn to show the separation of the years 1750, 2000 and 2100.

there are significant differences in the change of low-cloud cover $(\triangle \mathrm{LCF})$, not only between different emission conditions, but also between nucleation mechanisms. While binary nucleation simulations show a large change in cloud albedo since the pre-industrial period, $6.1-6.2 \%$, the increase in low-cloud cover (ranging from +1.2 to $+1.4 \%$ ) is more modest than with boundary layer nucleation included (from +1.4 to $+1.8 \%$ ). All SULACT and ORGSULACT experiments show a similar change in cloud albedo, $4.5 \%$, and the highest (lowest) increase in low-cloud cover corresponds to the highest (lowest) change in shortwave cloud forcing.

With the exception of SULACT experiment with RCP4.5 emission pathway, MEGAN2 emissions lead to a higher decrease in low-cloud cover. Averaged over all future pathways, MEGAN2 and LPJ-GUESS emissions lead to a decrease in the low-cloud cover of $-1.3 \%$ and $-1.0 \%$, respectively. While the global changes in the cloud cover in Table 5 are significant, their spatial distribution is mostly lost in the internal variation of the model. However, there is some indication that most of the cloud cover changes take place in North America and a band extending from Europe to Siberia. Also, the areas showing an increased cloud cover from the pre-industrial to present-day correlate with the areas showing a decrease in cloud cover in the future.

\section{Conclusions}

We have studied the role of biogenic VOC emissions and atmospheric new particle formation in pre-industrial, presentday and future conditions. The model ECHAM5.5-HAM2 was evaluated against field observations using present-day emissions. Simulated total aerosol number concentrations from primary emissions and binary sulphuric acid-water 
Table 5. Change in cloud albedo $\Delta \mathrm{Rc}(\%)$, low-cloud fraction $\Delta \mathrm{LCF}(\%)$ and shortwave cloud forcing at top-of-atmosphere $\Delta \mathrm{SWCF}$ $\left(\mathrm{W} \mathrm{m}^{-2}\right)$, calculated with respect to either pre-industrial or present-day.

\begin{tabular}{|c|c|c|c|c|c|c|c|c|c|c|c|c|c|}
\hline \multirow{3}{*}{$\begin{array}{l}\text { Nucleation } \\
\text { mechanism }\end{array}$} & \multirow{3}{*}{$\begin{array}{l}\text { BVOC } \\
\text { emission }\end{array}$} & \multicolumn{3}{|c|}{ Year 2000} & \multicolumn{9}{|c|}{ Year 2100} \\
\hline & & & & & & RCP-2 & & & RCP-4 & & & RCP-8 & 8.5 \\
\hline & & $\Delta \mathrm{Rc}^{1}$ & $\Delta \mathrm{LCF}^{1}$ & $\Delta \mathrm{SWCF}^{1}$ & $\Delta \mathrm{Rc}^{2}$ & $\Delta \mathrm{LCF}^{2}$ & $\Delta \mathrm{SWCF}^{2}$ & $\Delta \mathrm{Rc}^{2}$ & $\Delta \mathrm{LCF}^{2}$ & $\triangle \mathrm{SWCF}^{2}$ & $\Delta \mathrm{Rc}^{2}$ & $\Delta \mathrm{LCF}^{2}$ & $\Delta \mathrm{SWCF}^{2}$ \\
\hline \multirow{2}{*}{ BINARY } & & +6.06 & & & 405 & -1.13 & & -4.96 & -0.81 & & -4.25 & -1.02 & \\
\hline & ESS & 5.20 & +1.22 & & -4.89 & -0.90 & & & -0.9 & +1. & & -1.00 & \\
\hline \multirow{2}{*}{ SULACT } & EGAN2 & 4.49 & +1.76 & -1.54 & -4.08 & -1.48 & .39 & -3.75 & -0.99 & +1.11 & -3.43 & -1.52 & 1.17 \\
\hline & LPJ-GUESS & 4.42 & +1.82 & & -4.05 & -1.01 & & -3.74 & -1.13 & & -3 . & -0.96 & 1.08 \\
\hline \multirow{2}{*}{ ORGSULACT } & MEGAN2 & +4.43 & +1.74 & -1.62 & -4.11 & -1.70 & +1.53 & -3.84 & -1.16 & +1.22 & -3.40 & -1.25 & +1.12 \\
\hline & LPJ-GUESS & +4.45 & +1.43 & & & -1.01 & & -3.76 & -0.82 & +0.99 & -3.30 & -1.05 & +1.01 \\
\hline ORGSULHET & MEGAN2 & +5.73 & +1.84 & -1.62 & -4.98 & -1.34 & +1.23 & - & - & - & - & - & - \\
\hline SULACT_TER & MEGAN2 & +6.33 & +1.79 & -1.67 & -5.37 & -1.60 & +1.47 & - & - & - & - & - & - \\
\hline
\end{tabular}

${ }^{1}$ (Present-day)-(Pre-industrial), ${ }^{2}$ (Future)-(Present-day)

nucleation were not able to capture the observed concentration levels or their monthly variation. It was shown that activation-type nucleation by sulphuric acid generally overpredicted aerosol number concentrations, whereas activation-type nucleation with sulphuric acid and organics gave the best agreement to observations.

The agreement between modeled and observed presentday aerosol concentrations gave confidence to use the model also in pre-industrial (year 1750) and future (year 2100) conditions. We have shown earlier (Makkonen et al., 2012) that the present-day total radiative forcing is highly sensitive to whether atmospheric nucleation is included in the model or not. Here, we have shown that the present-day cloud forcing is rather insensitive to the chosen boundary layer nucleation scheme. The change in shortwave cloud forcing from preindustrial to present-day, calculated with several boundary layer nucleation schemes and the two BVOC emission models, ranged from -1.5 to $-1.8 \mathrm{~W} \mathrm{~m}^{-2}$. The change in cloud forcing from present-day until year 2100 varied from +1.0 to $+1.5 \mathrm{~W} \mathrm{~m}^{-2}$, when boundary layer nucleation was included in the model.

We applied BVOC emissions from two models, MEGAN2 and LPJ-GUESS. The models differed in terms of the spatial distribution of emissions and the global emission strength, by a factor of 2.7-3.5. Although the higher global emissions of MEGAN2 led to 2-3\% higher present-day global average CCN concentrations than LPJ-GUESS, there were substantial differences in the spatial CCN distribution between the two BVOC models. The spatial distribution of LPJGUESS emissions correlated with anthropogenic emissions better than MEGAN2 emissions, enhancing the conversion of anthropogenic emissions to $\mathrm{CCN}$. The future decrease in anthropogenic emissions led to a decrease in $\mathrm{CCN}$ concentration, but the simultaneous increase in the BVOC emissions according to MEGAN2 counteracted this decrease in CCN concentration. The correlation of anthropogenic emissions and the BVOC emissions from LPJ-GUESS continued until year 2100: although the global BVOC emission strength of MEGAN2 is more than three times that of LPJ-GUESS in the year 2100, the BVOCs from LPJ-GUESS led to more $\mathrm{CCN}$ in large part of the Northern Hemisphere than the emissions from MEGAN2.

The emissions of MEGAN2 led to higher CDNC in the lower troposphere than the emissions of LPJ-GUESS, especially in the year 2100 , as the $\mathrm{CO}_{2}$ inhibition in LPJ-GUESS led to a decrease in future BVOC emission. However, the effect of BVOC on CDNC at cloud-top was almost indistinguishable. While the changes in cloud albedo between present-day and future were similar between MEGAN2 and LPJ-GUESS, the model indicated a larger future decrease in low-cloud cover with MEGAN2 emissions. The changes in cloud cover seemed to dominate the resulting change in cloud forcing. Averaged over the future emission pathways, LPJ-GUESS led to a change of $1.2 \mathrm{~W} \mathrm{~m}^{-2}$ in the cloud forcing between years 2000 and 2100, while the change was $1.3 \mathrm{~W} \mathrm{~m}^{-2}$ with MEGAN2 emissions. This implies that although the increasing BVOC concentrations would act to increase the $\mathrm{CCN}$ concentrations, the indirect effects beyond the cloud albedo effect can have a large contribution on the resulting climate effect. However, the magnitude, and even the sign of the feedback is likely to be very sensitive to the treatment of organic vapours and to the spatial distribution of both the anthropogenic emissions and BVOC emissions.

\section{Supplementary material related to this article is available online at: http://www.atmos-chem-phys.net/12/ 10077/2012/acp-12-10077-2012-supplement.pdf.}

Acknowledgements. We thank Kai Zhang for providing the RCP emission fields. The financial support by the Academy of Finland Centre of Excellence program (project no. 1118615) is gratefully acknowledged. We thank the Finnish IT center for science (CSC) for technical support and computing time. A. Arneth acknowledges support from the Swedish Research Councils Formas and Vetenskapsrådet. M. K. acknowledges support from the European Research Counsil Advanced Grant (no. 227463). 
Edited by: D. Spracklen

\section{References}

Abdul-Razzak, H. and Ghan, S. J.: A parameterization of aerosol activation 2. Multiple aerosol types, J. Geophys. Res., 105, 68376844, 2000.

Albrecht, B. A.: Aerosol, cloud microphysics, and fractional cloudiness, Science, 245, 1227-1230, 1989.

Amiro, B., Cantin, A., Flannigan, M., and de Groot, W.: Future emissions from Canadian boreal forest fires, Can. J. Forest Res., 39, 383-395, 2009.

Andreae, M., Jones, C., and Cox, P.: Strong present-day cooling implies a hot future, Nature, 435, 1187-1190, 2005.

Arneth, A., Miller, P. A., Scholze, M., Hickler, T., Schurgers, G., Smith, B., and Prentice, I. C.: $\mathrm{CO}_{2}$ inhibition of global terrestrial isoprene emissions: Potential implications for atmospheric chemistry, Geophys. Res. Lett., 34, L18813, doi:10.1029/2007GL030615, 2007.

Arneth, A., Monson, R. K., Schurgers, G., Niinemets, Ü., and Palmer, P. I.: Why are estimates of global terrestrial isoprene emissions so similar (and why is this not so for monoterpenes)?, Atmos. Chem. Phys., 8, 4605-4620, doi:10.5194/acp-8-46052008, 2008.

Arneth, A., Schurgers, G., Lathiere, J., Duhl, T., Beerling, D. J., Hewitt, C. N., Martin, M., and Guenther, A.: Global terrestrial isoprene emission models: sensitivity to variability in climate and vegetation, Atmos. Chem. Phys., 11, 8037-8052, doi:10.5194/acp-11-8037-2011, 2011.

Brenguier, J.-L., Pawlowska, H., Schüller, L., Preusker, R., Fischer, J., and Fouquart, Y.: Radiative Properties of Boundary Layer Clouds: Droplet Effective Radius versus Number Concentration, J. Atmos. Sci., 57, 803-821, doi:10.1175/15200469(2000)057<0803:RPOBLC>2.0.CO;2, 2000.

Carslaw, K. S., Boucher, O., Spracklen, D. V., Mann, G. W., Rae, J. G. L., Woodward, S., and Kulmala, M.: A review of natural aerosol interactions and feedbacks within the Earth system, Atmos. Chem. Phys., 10, 1701-1737, doi:10.5194/acp-10-17012010, 2010.

Charlson, R. J., Lovelock, J. E., Andreas, M. D., and Warren, S. G.: Oceanic phytoplankton, atmospheric sulphur, cloud albedo and climate, Nature, 326, 655-661, 1987.

Cheng, T., Peng, Y., Feichter, J., and Tegen, I.: An improvement on the dust emission scheme in the global aerosol-climate model ECHAM5-HAM, Atmos. Chem. Phys., 8, 1105-1117, doi:10.5194/acp-8-1105-2008, 2008.

Clarke, L., Edmonds, J., Jacoby, H., Pitcher, H., Reilly, J., and Richels, R.: Scenarios of Greenhouse Gas Emissions and Atmospheric Concentrations, Sub-report 2.1A of Synthesis and Assessment Product 2.1 by the U.S. Climate Change Science Program and the Subcommittee on Global Change Research, Department of Energy, Office of Biological \& Environmental Research, Washington, 7 DC, USA, 2007.

Dentener, F., Kinne, S., Bond, T., Boucher, O., Cofala, J., Generoso, S., Ginoux, P., Gong, S., Hoelzemann, J. J., Ito, A., Marelli, L., Penner, J. E., Putaud, J.-P., Textor, C., Schulz, M., van der Werf, G. R., and Wilson, J.: Emissions of primary aerosol and precursor gases in the years 2000 and 1750 prescribed data-sets for Ae-
roCom, Atmos. Chem. Phys., 6, 4321-4344, doi:10.5194/acp-64321-2006, 2006.

Devasthale, A., Krueger, O., and Grassl, H.: Change in cloud-top temperatures over Europe, IEEE Geosci. Remote Sens. Lett., 2, 333-336, doi:10.1109/LGRS.2005.851736, 2005.

Donahue, N. M., Epstein, S. A., Pandis, S. N., and Robinson, A. L.: A two-dimensional volatility basis set: 1. organic-aerosol mixing thermodynamics, Atmos. Chem. Phys., 11, 3303-3318, doi:10.5194/acp-11-3303-2011, 2011.

Forster, P., Ramaswamy, V., Artaxo, P., Berntsen, T., Betts, R., Fahey, D. W., Haywood, J., Lean, J., Lowe, D. C., Myhre, G., Nganga, J., Prinn, R., Raga, G., Schulz, M., and Van Dorland, R.: Climate Change 2007, The Physical Science Basis, Contribution of Working Group I to the Fourth Assessment Report of the Intergovernmental Panel on Climate Change, Cambridge Univ. Press, Cambridge, United Kingdom, and New York, NY, USA, 2007.

Gillett, N. P., Weaver, A. J., Zwiers, F. W., and Flannigan, M. D.: Detecting the effect of climate change on Canadian forest fires, Geophys. Res. Lett., 31, L18211, doi:10.1029/2004GL020876, 2004.

Guelle, W., Schulz, M., Balkanski, Y., and Dentener, F.: Influence of the source formulation on modeling the atmospheric global distribution of sea salt aerosol, J. Geophys. Res., 106, 2750927524, doi:10.1029/2001JD900249, 2001.

Guenther, A., Monson, R., and Fall, R.: Isoprene and Monoterpene Emission Rate Variability: Observations With Eucalyptus and Emission Rate Algorithm Development, J. Geophys. Res., 96, 10799-10808, doi:10.1029/91JD00960, 1991.

Guenther, A., Karl, T., Harley, P., Wiedinmyer, C., Palmer, P. I., and Geron, C.: Estimates of global terrestrial isoprene emissions using MEGAN (Model of Emissions of Gases and Aerosols from Nature), Atmos. Chem. Phys., 6, 3181-3210, doi:10.5194/acp-63181-2006, 2006.

Hansen, J., Sato, M., Kharecha, P., and von Schuckmann, K.: Earth's energy imbalance and implications, Atmos. Chem. Phys., 11, 13421-13449, doi:10.5194/acp-11-13421-2011, 2011.

Heald, C., Wilkinson, M., Monson, R., Alo, C., Wang, G., and Guenther, A.: Response of isoprene emission to ambient CO. changes and implications for global budgets, Glob. Change Biol., 15, 1127-1140, doi:10.1111/j.1365-2486.2008.01802.x, 2009.

Kerminen, V. M. and Kulmala, M.: Analytical formulae connecting the "real" and the "apparent" nucleation rate and the nuclei number concentration for atmospheric nucleation events, J. Aerosol Sci., 33, 609-622, 2002.

Kloster, S., Dentener, F., Feichter, J., Raes, F., van Aardenne, J., Roeckner, E., Lohmann, U., Stier, P., and Swart, R.: Influence of future air pollution mitigation strategies on total aerosol radiative forcing, Atmos. Chem. Phys., 8, 6405-6437, doi:10.5194/acp-86405-2008, 2008.

Koren, I., Kaufman, Y. J., Rosenfeld, D., Remer, L. A., and Rudich, Y: Aerosol invigoration and restructuring of Atlantic convective clouds, Geophys. Res. Lett., 32, L14828, doi:10.1029/2005GL023187, 2005.

Korhonen, H., Carslaw, K. S., Forster, P. M., Mikkonen, S., Gordon, N. D., and Kokkola, H.: Aerosol climate feedback due to decadal increases in Southern Hemisphere wind speeds, Geophys. Res. Lett., 37, L02805, doi:10.1029/2009GL041320, 2010. 
Kulmala, M., Suni, T., Lehtinen, K. E. J., Dal Maso, M., Boy, M., Reissell, A., Rannik, Ü., Aalto, P., Keronen, P., Hakola, H., Bäck, J., Hoffmann, T., Vesala, T., and Hari, P.: A new feedback mechanism linking forests, aerosols, and climate, Atmos. Chem. Phys., 4, 557-562, doi:10.5194/acp-4-557-2004, 2004.

Kulmala, M., Lehtinen, K. E. J., and Laaksonen, A.: Cluster activation theory as an explanation of the linear dependence between formation rate of $3 \mathrm{~nm}$ particles and sulphuric acid concentration, Atmos. Chem. Phys., 6, 787-793, doi:10.5194/acp-6-787-2006, 2006.

Lamarque, J.-F., Kyle, G., Meinshausen, M., Riahi, K., Smith, S., van Vuuren, D., Conley, A., and Vitt, F.: Global and regional evolution of short-lived radiatively-active gases and aerosols in the Representative Concentration Pathways, Clim. Change, 109, 191-212, doi:10.1007/s10584-011-0155-0, 2011.

Langley, L., Leaitch, W. R., Lohmann, U., Shantz, N. C., and Worsnop, D. R.: Contributions from DMS and ship emissions to $\mathrm{CCN}$ observed over the summertime North Pacific, Atmos. Chem. Phys., 10, 1287-1314, doi:10.5194/acp-10-1287-2010, 2010.

Lohmann, U., Stier, P., Hoose, C., Ferrachat, S., Kloster, S., Roeckner, E., and Zhang, J.: Cloud microphysics and aerosol indirect effects in the global climate model ECHAM5-HAM, Atmos. Chem. Phys., 7, 3425-3446, doi:10.5194/acp-7-3425-2007, 2007.

Makkonen, R., Asmi, A., Korhonen, H., Kokkola, H., Järvenoja, S., Räisänen, P., Lehtinen, K. E. J., Laaksonen, A., Kerminen, V.M., Järvinen, H., Lohmann, U., Bennartz, R., Feichter, J., and Kulmala, M.: Sensitivity of aerosol concentrations and cloud properties to nucleation and secondary organic distribution in ECHAM5-HAM global circulation model, Atmos. Chem. Phys., 9, 1747-1766, doi:10.5194/acp-9-1747-2009, 2009.

Makkonen, R., Asmi, A., Kerminen, V.-M., Boy, M., Arneth, A., Hari, P., and Kulmala, M.: Air pollution control and decreasing new particle formation lead to strong climate warming, Atmos. Chem. Phys., 12, 1515-1524, doi:10.5194/acp-12-15152012, 2012.

Merikanto, J., Spracklen, D. V., Mann, G. W., Pickering, S. J., and Carslaw, K. S.: Impact of nucleation on global CCN, Atmos. Chem. Phys., 9, 8601-8616, doi:10.5194/acp-9-8601-2009, 2009.

Merikanto, J., Spracklen, D. V., Pringle, K. J., and Carslaw, K. S.: Effects of boundary layer particle formation on cloud droplet number and changes in cloud albedo from 1850 to 2000, Atmos. Chem. Phys., 10, 695-705, doi:10.5194/acp-10-695-2010, 2010.

Meskhidze, N., Xu, J., Gantt, B., Zhang, Y., Nenes, A., Ghan, S. J., Liu, X., Easter, R., and Zaveri, R.: Global distribution and climate forcing of marine organic aerosol: 1. Model improvements and evaluation, Atmos. Chem. Phys., 11, 11689-11705, doi:10.5194/acp-11-11689-2011, 2011.

Metzger, A., Verheggen, B., Dommen, J., Duplissy, J., Prevot, A. S. H., Weingartner, E., Riipinen, I., Kulmala, M., Spracklen, D. V., Carslaw, K. S., and Baltensperger, U.: Evidence for the role of organics in aerosol particle formation under atmospheric conditions, P. Natl. Acad. Sci., 107, 6646-6651, doi:10.1073/pnas.0911330107, 2010.

Moss, R. H., Edmonds, J. A., Hibbard, K. A., Manning, M. R., Rose, S. K., van Vuuren, D. P., Carter, T. R., Emori, S., Kainuma, M., Kram, T., Meehl, G. A., Mitchell, J. F. B., Nakicenovic, N., Ri- ahi, K., Smith, S. J., Stouffer, R. J., Thomson, A. M., Weyant, J. P., and Wilbanks, T. J.: The next generation of scenarios for climate change research and assessment, Nature, 463, 747-756, doi:10.1038/nature08823, 2010.

Niinemets, U., Tenhunen, J., Harley, P., and Steinbrecher, R.: A model of isoprene emission based on energetic requirements for isoprene synthesis and leaf photosynthetic properties for Liquidambar and Quercus, Plant Cell Environ., 22, 1319-1335, 1999.

O'Donnell, D., Tsigaridis, K., and Feichter, J.: Estimating the direct and indirect effects of secondary organic aerosols using ECHAM5-HAM, Atmos. Chem. Phys., 11, 8635-8659, doi:10.5194/acp-11-8635-2011, 2011.

Ortega, I. K., Suni, T., Boy, M., Grönholm, T., Manninen, H. E., Nieminen, T., Ehn, M., Junninen, H., Hakola, H., Hellén, H., Valmari, T., Arvela, H., Zegelin, S., Hughes, D., Kitchen, M., Cleugh, H., Worsnop, D. R., Kulmala, M., and Kerminen, V.-M.: New insights into nocturnal nucleation, Atmos. Chem. Phys., 12, 4297-4312, doi:10.5194/acp-12-4297-2012, 2012.

Paasonen, P., Nieminen, T., Asmi, E., Manninen, H. E., Petäjä, T., Plass-Dülmer, C., Flentje, H., Birmili, W., Wiedensohler, A., Hõrrak, U., Metzger, A., Hamed, A., Laaksonen, A., Facchini, M. C., Kerminen, V.-M., and Kulmala, M.: On the roles of sulphuric acid and low-volatility organic vapours in the initial steps of atmospheric new particle formation, Atmos. Chem. Phys., 10, 11223-11242, doi:10.5194/acp-10-11223-2010, 2010.

Pierce, J. R. and Adams, P. J.: Uncertainty in global CCN concentrations from uncertain aerosol nucleation and primary emission rates, Atmos. Chem. Phys., 9, 1339-1356, doi:10.5194/acp-91339-2009, 2009.

Pincus, R. and Baker, M. B.: Effect of precipitation on the albedo susceptibility of clouds in the marine boundary layer, Nature, 372, 250-252, doi:10.1038/372250a0, 1994.

Quaas, J., Ming, Y., Menon, S., Takemura, T., Wang, M., Penner, J. E., Gettelman, A., Lohmann, U., Bellouin, N., Boucher, O., Sayer, A. M., Thomas, G. E., McComiskey, A., Feingold, G., Hoose, C., Kristjánsson, J. E., Liu, X., Balkanski, Y., Donner, L. J., Ginoux, P. A., Stier, P., Grandey, B., Feichter, J., Sednev, I., Bauer, S. E., Koch, D., Grainger, R. G., Kirkevåg, A., Iversen, T., Seland, Ø., Easter, R., Ghan, S. J., Rasch, P. J., Morrison, H., Lamarque, J.-F., Iacono, M. J., Kinne, S., and Schulz, M.: Aerosol indirect effects - general circulation model intercomparison and evaluation with satellite data, Atmos. Chem. Phys., 9, 8697-8717, doi:10.5194/acp-9-8697-2009, 2009.

Räisänen, T., Ryyppö, A., and Kellomäki, S.: Effects of elevated $\mathrm{CO}_{2}$ and temperature on monoterpene emission of Scots pine (Pinus sylvestris L.), Atmos. Environ., 42, 4160-4171, doi:10.1016/j.atmosenv.2008.01.023, 2008.

Riahi, K., Gruebler, A., and Nakicenovic, N.: Scenarios of longterm socio-economic and environmental development under climate stabilization, Technol. Forecast. Soc., 74, 887-935, doi:10.1016/j.techfore.2006.05.026, 2007.

Riipinen, I., Pierce, J. R., Yli-Juuti, T., Nieminen, T., Häkkinen, S., Ehn, M., Junninen, H., Lehtipalo, K., Petäjä, T., Slowik, J., Chang, R., Shantz, N. C., Abbatt, J., Leaitch, W. R., Kerminen, V.-M., Worsnop, D. R., Pandis, S. N., Donahue, N. M., and Kulmala, M.: Organic condensation: a vital link connecting aerosol formation to cloud condensation nuclei (CCN) concentrations, Atmos. Chem. Phys., 11, 3865-3878, doi:10.5194/acp-11-3865- 
2011, 2011.

Schurgers, G., Arneth, A., Holzinger, R., and Goldstein, A. H.: Process-based modelling of biogenic monoterpene emissions combining production and release from storage, Atmos. Chem. Phys., 9, 3409-3423, doi:10.5194/acp-9-3409-2009, 2009.

Smith, S. and Wigley, T.: Multi-Gas Forcing Stabilization with the MiniCAM, Energy J. (Special Issue \#3), 27, 373-391, 2006.

Spracklen, D. V., Carslaw, K. S., Kulmala, M., Kerminen, V.-M., Mann, G. W., and Sihto, S.-L.: The contribution of boundary layer nucleation events to total particle concentrations on regional and global scales, Atmos. Chem. Phys., 6, 5631-5648, doi:10.5194/acp-6-5631-2006, 2006.

Spracklen, D. V., Carslaw, K. S., Merikanto, J., Mann, G. W., Reddington, C. L., Pickering, S., Ogren, J. A., Andrews, E., Baltensperger, U., Weingartner, E., Boy, M., Kulmala, M., Laakso, L., Lihavainen, H., Kivekäs, N., Komppula, M., Mihalopoulos, N., Kouvarakis, G., Jennings, S. G., O’Dowd, C., Birmili, W., Wiedensohler, A., Weller, R., Gras, J., Laj, P., Sellegri, K., Bonn, B., Krejci, R., Laaksonen, A., Hamed, A., Minikin, A., Harrison, R. M., Talbot, R., and Sun, J.: Explaining global surface aerosol number concentrations in terms of primary emissions and particle formation, Atmos. Chem. Phys., 10, 4775-4793, doi:10.5194/acp-10-4775-2010, 2010.

Stier, P., Feichter, J., Kinne, S., Kloster, S., Vignati, E., Wilson, J., Ganzeveld, L., Tegen, I., Werner, M., Balkanski, Y., Schulz, M., Boucher, O., Minikin, A., and Petzold, A.: The aerosol-climate model ECHAM5-HAM, Atmos. Chem. Phys., 5, 1125-1156, doi:10.5194/acp-5-1125-2005, 2005.

Stier, P. et al.: Mechanistic Aerosol-Cloud Coupling and Indirect Aerosol Effects in the aerosol-climate model ECHAM-HAM, in preparation, 2012.

Tegen, I., Harrison, S. P., Kohfeld, K., Prentice, I. C., Coe, M., and Heimann, M.: Impact of vegetation and preferential source areas on global dust aerosol: Results from a model study, J. Geophys. Res., 107, 4576, doi:10.1029/2001JD000963, 2002.

Tegen, I., Werner, M., Harrison, S. P., and Kohfeld, K. E.: Relative importance of climate and land use in determining present and future global soil dust emission, Geophys. Res. Lett., 31, L05105, doi:10.1029/2003GL019216, 2004.

Timmreck, C. and Schulz, M.: Significant dust simulation differences in nudged and climatological operation mode of the AGCM ECHAM, J. Geophys. Res., 109, D13202, doi:10.1029/2003JD004381, 2004.

Twomey, S.: Pollution and the planetary albedo, Atmos. Environ., $8,1251-1256,1974$.
Twomey, S.: Aerosols, clouds and radiation, Atmos. Environ., 25A, 2435-2442, 1991.

van Vuuren, D. P., den Elzen, M. G. J., Lucas, P. L., Eickhout, B., Strengers, B. J., van Ruijven, B., Wonink, S., and van Houdt, R.: Stabilizing greenhouse gas concentrations at low levels: an assessment of reduction strategies and costs, Clim. Change, 81, 119-159, doi:10.1007/s10584-006-9172-9, 2007.

Vehkamäki, H., Kulmala, M., Napari, I., Lehtinen, K. E. J., Timmreck, C., Noppel, M., and Laaksonen, A.: An improved parameterization for sulfuric acid/water nucleation rates for tropospheric and stratospheric conditions, J. Geophys. Res., 107, 4622-4631, 2002.

Vignati, E., Wilson, J., and Stier, P.: M7: An efficient size-resolved aerosol microphysics module for large-scale aerosol transport models, J. Geophys. Res., 109, D22202, doi:10.1029/2003JD004485, 2004.

Wang, M. and Penner, J. E.: Aerosol indirect forcing in a global model with particle nucleation, Atmos. Chem. Phys., 9, 239-260, doi:10.5194/acp-9-239-2009, 2009.

Westerling, A. L., Hidalgo, H. G., Cayan, D. R., and Swetnam, T. W.: Warming and Earlier Spring Increase Western U.S. Forest Wildfire Activity, Science, 313, 940-943, doi:10.1126/science.1128834, 2006.

Wise, M., Calvin, K., Thomson, A., Clarke, L., Bond-Lamberty, B., Sands, R., Smith, S. J., Janetos, A., and Edmonds, J.: Implications of Limiting $\mathrm{CO}_{2}$ Concentrations for Land Use and Energy, Science, 324, 1183-1186, doi:10.1126/science.1168475, 2009.

Yli-Juuti, T., Nieminen, T., Hirsikko, A., Aalto, P. P., Asmi, E., Hõrrak, U., Manninen, H. E., Patokoski, J., Dal Maso, M., Petäjä, T., Rinne, J., Kulmala, M., and Riipinen, I.: Growth rates of nucleation mode particles in Hyytiälä during 20032009: variation with particle size, season, data analysis method and ambient conditions, Atmos. Chem. Phys., 11, 12865-12886, doi:10.5194/acp-11-12865-2011, 2011.

$\mathrm{Yu}, \mathrm{F} .:$ A secondary organic aerosol formation model considering successive oxidation aging and kinetic condensation of organic compounds: global scale implications, Atmos. Chem. Phys., 11, 1083-1099, doi:10.5194/acp-11-1083-2011, 2011.

Zhang, K., O’Donnell, D., Kazil, J., Stier, P., Kinne, S., Lohmann, U., Ferrachat, S., Croft, B., Quaas, J., Wan, H., Rast, S., and Feichter, J.: The global aerosol-climate model ECHAM-HAM, version 2: sensitivity to improvements in process representations, Atmos. Chem. Phys., 12, 8911-8949, doi:10.5194/acp-12-89112012, 2012. 